\title{
Development of Models for the Estimation of Mouth Level Exposure to Aerosol Constituents from a Heat- Not-Burn Tobacco Product Using Mouthpiece Analysis*
}

\author{
by \\ Laurent Poget, Pedro Campelos, Cyril Jeannet, and Serge Maeder \\ Philip Morris International, Quai Jeanrenaud 5, 2000 Neuchâtel, Switzerland
}

\section{SUMMARY}

Philip Morris International has developed a heat-not-burn tobacco heating system (THS 2.2) that produces an aerosol without combustion. Adult smokers are anticipated to use the product with differing behaviors, such as puffing volume or puffing frequency, therefore it was important to find an easy way to study how users are exposed to the aerosol constituents. Thus, the intended outcome of this study was to propose and assess a simple approach for the estimation of THS users' exposure to harmful and potentially harmful constituents (HPHCs).

THS operates using tobacco sticks (HeatSticks) that include a mouthpiece and a tobacco plug which, when heated, generates an aerosol. The analysis of nicotine retained in the mouthpiece of the HeatSticks during use was identified as a potential approach to estimate users' mouth level exposure (MLE) to HPHCs. Consequently, the following study was conducted with the objectives 1.) to assess the correlation between the quantity of retained nicotine in the mouthpiece (Nicotine MP) of the HeatSticks and the nicotine delivered in the aerosol of machine-smoked products, 2.) to verify the practical range for Nicotine MP based on the analysis of used HeatSticks left by THS users, and 3.) to develop models describing the relationship between Nicotine MP and specific aerosol constituents measured in the aerosol of machine-smoked products.

The regular non-mentholated HeatSticks variant was machine-smoked under various smoking regimens to cover the range of anticipated human puffing behaviors. The suitability of this practical range of machine-smoking conditions was verified by collecting used HeatSticks from two different trials conducted with THS users. The determined Nicotine MP distribution indicated that the machinesmoked regimens encompassed the range observed for users.

Multiple Linear Regression (MLR) combined with a stepwise approach was used for selecting models describing the relationship between Nicotine MP and specific aerosol constituents. The stepwise approach interactively explores which amongst various tested predictors provides a good fit. The developed models showed good adjusted coefficients of determination (i.e., $\mathrm{R}^{2}$ adj. $\geq 0.75$ ) for 28 out of the 43 investigated HPHCs.

Previously published studies showed that actual MLE can be estimated from cigarette filter analysis. This study demonstrated that the analysis of nicotine in THS mouthpiece (filter section) corresponded to an estimation of the upper limits of MLE, in line with maximum possible usage conditions. [Beitr. Tabakforsch. Int. 27 (2017) 42-64]

\section{ZUSAMMENFASSUNG}

Philip Morris International hat ein Tabak-Heizsystem (THS 2.2) entwickelt, welches ein Aerosol auf der Basis von Erhitzung statt Verbrennung von Tabak erzeugt. Erwachsene Raucher werden das THS möglicherweise unterschiedlich benutzen, typische Parameter wie Zugvolumen oder Zugfrequenz können variieren, weshalb es wichtig war, eine einfache Methode zur Untersuchung der Exposition von Nutzern gegenüber den Aerosolinhalts- 
stoffen zu finden. Das Ziel der vorliegenden Studie war es, eine Möglichkeit zur Abschätzung der Exposition von THS-Nutzern gegenüber schädlichen und potentiell schädlichen Bestandteilen (HPHCs) vorzuschlagen und zu evaluieren.

THS basiert auf der Verwendung sogenannter HeatSticks, welche unter anderem aus einem Mundstück mit Filter und einem Tabakstrang bestehen, der bei Erhitzung ein Aerosol erzeugt. Die analytische Bestimmung von Nikotinrückständen im Mundstückfilter nach Gebrauch wurde als potentielle Methode identifiziert, um die Mundraumexposition (MLE) von THS-Nutzern gegenüber den HPHCs abzuschätzen.

Das Ziel der vorliegenden Studie war folglich 1.) die Korrelation zwischen der Menge an Nikotinrückständen im Mundstückfilter (Nicotine MP) der HeatSticks und dem Nikotingehalt in dem von Rauchmaschinen generierten Aerosol zu ermitteln, 2.) den Anwendungsbereich basierend auf der Analyse von benutzten HeatSticks zu verifizieren und 3.) Modelle zur Beschreibung der Beziehung zwischen Nikotinrückständen im Mundstückfilter (Nicotine MP) und bestimmten Aerosolinhaltsstoffen zu entwickeln. Aerosol von einer mentholfreien HeatSticks Variante wurde maschinell mit verschiedenen Abrauchverfahren generiert, um den Bereich des erwarteten menschlichen Rauchverhaltens abzudecken. Die Eignung der gewählten maschinellen Abrauchverfahren wurde anhand benutzter HeatSticks verifiziert, die während zwei unabhängiger Tests mit THS-Nutzern gesammelt wurden.

Die Verteilung der analytisch bestimmten Nikotinrückstände im Mundstückfilter zeigte, dass die maschinellen Abrauchverfahren den Bereich von THS-Nutzern gut umfassten. Die Beziehung von Nikotinrückständen in Mundstückfiltern und bestimmten Aerosolinhaltsstoffen wurde mithilfe von schrittweisen multiplen linearen Regressionsmodellen untersucht. Bei der schrittweisen Regression wurden nach jedem Schritt Prädiktoren hinzugefügt (bei Rückwärtselimination entfernt), die einen zusätzlichen Beitrag im Modell leisten. Die mit dieser Methode entwickelten Regressionsmodelle zeigten ein gutes Bestimmtheitsmaß (Bestimmtheitsmaß $\mathrm{R}^{2}$ adj. $\geq$ 0.75 ) für 28 der 43 untersuchten HPHCs. Bereits veröffentlichte Studien haben gezeigt, dass die Exposition im Mundraum durch die Analyse von Zigarettenfiltern abgeschätzt werden kann. Die aktuelle Studie hat gezeigt, dass die analytische Bestimmung von Nikotin im THS-Mundstückfilter eine Abschätzung der Obergrenze der Mundraumexposition unter realen Nutzungsbedingungen ermöglicht. [Beitr. Tabakforsch. Int. 27 (2017) 42-64]

\section{RESUME}

Philip Morris International a développé un dispositif de tabac chauffé (THS 2.2) qui produit un aérosol sans combustion. Il faut s'attendre de la part des fumeurs adultes qu'ils utilisent le produit de façon différente en termes de volume ou de fréquence des bouffées, et de ce fait, il devient important de trouver une approche pratique pour évaluer l'exposition des utilisateurs aux composants de l'aérosol. Le but de cette étude est donc de proposer et d'évaluer une méthode simple visant à estimer l'exposition des utilisateurs de dispositifs de tabac chauffé (THS) aux composés nocifs ou potentiellement nocifs (HPHCs).

Le THS utilise un bâtonnet de tabac (HeatSticks), constitué d'un filtre situé côté bouche et d'une portion de tabac qui chauffé produit un aérosol. L'analyse de la nicotine retenue dans le filtre lors de l'utilisation du HeatSticks est un indicateur éventuel pour estimer l'exposition aux composés nocifs ou potentiellement nocifs mesurée au niveau de la bouche (MLE). Par conséquent, cette étude a pour objectifs 1.) d'évaluer la corrélation entre la quantité de nicotine retenue dans le filtre (Nicotine MP) des HeatSticks par rapport à la quantité de nicotine de l'aérosol délivré, ceci dans des conditions d'utilisation reproduites avec des machines à fumer, 2.) de vérifier le domaine effectif des valeurs de Nicotine MP couvert par l'analyse de HeatSticks consommés et récupérés auprès d'utilisateurs de THS et 3.) de développer des modèles décrivant la relation entre les niveaux de Nicotine MP et de composants spécifiques de l'aérosol délivrés dans des conditions d'utilisation reproduites avec des machines à fumer.

Une variante non mentholée de HeatSticks a été évaluée en utilisant un machine à fumer pour la production d'aérosol sous différents régimes jugés couvrir raisonnablement les conditions humaines d'utilisations du produit. La pertinence du domaine utilisé pour les conditions d'utilisation en machine a été vérifiée en collectant des HeatSticks usagés lors de deux campagnes de tests indépendantes conduites avec des utilisateurs de THS. La distribution des valeurs de Nicotine MP a montré que les régimes appliqués avec les fumages en machines englobaient le domaine observé pour les utilisateurs.

Une méthode de régression linéaire multiple (MLR) combinée à une approche pas à pas a été appliquée à la sélection des modèles décrivant la relation entre Nicotine MP et des composants spécifiques de l'aérosol. Par le biais d'un procédé interactif, l'approche pas à pas explore quels sont parmi les prédicteurs testés ceux qui offrent la meilleure adéquation. Les modèles ainsi développés ont montré un bon coefficient de détermination ajusté (i.e., $\mathrm{R}^{2}$ adj. $\geq 0.75$ ) pour 28 des 43 composants nocifs ou potentiellement nocifs étudiés.

Des études publiées par le passé ont déjà montré que l'exposition aux composés nocifs ou potentiellement nocifs mesurée au niveau de la bouche (MLE) peut être estimée par l'analyse de la nicotine dans les filtres. Cette étude a démontré que l'analyse de nicotine dans les embouts de THS (le filtre) correspond à une estimation de limites supérieures d'exposition délivrées par les bouffées, qui sont en ligne avec les conditions maximales d'utilisation. [Beitr. Tabakforsch. Int. 27 (2017) 42-64]

\section{KEYWORDS}

Part-Filter Nicotine Analysis; Mouth Level Exposure; Multiple Linear Regression; Reduced Risk Product.

\section{ABBREVIATIONS}

APCI Atmospheric Pressure Chemical Ionization CL Confidence Limit 


$\begin{array}{ll}\text { CRM } & \text { CORESTA Recommended Method } \\ \text { EHCSS } & \begin{array}{l}\text { Electrically Heated Cigarette Smoking } \\ \text { System }\end{array} \\ \text { FAS } & \text { Full Analysis Set } \\ \text { FID } & \text { Flame Ionization Detection } \\ \text { HCI } & \text { Health Canada Intense } \\ \text { HPHC } & \text { Harmful and Potentially Harmful Con- } \\ & \text { stituents } \\ \text { HS } & \text { Human-Smoked } \\ \text { HST } & \text { Human Smoking Topography } \\ \text { IRQ } & \text { Interquartile Range } \\ \text { ISO } & \text { International Standard Organization } \\ \text { LLOQ } & \text { Lower Limit Of Quantification } \\ \text { LOD } & \text { Limit Of Detection } \\ \text { LR-3 } & \text { Specific Smoking Regimen } \\ \text { MEK } & \text { Methyl Ethyl Ketone } \\ \text { MLE } & \text { Mouth Level Exposure } \\ \text { MLR } & \text { Multiple Linear Regression } \\ \text { NAB } & N \text {-Nitrosoanabasine } \\ \text { NAT } & N \text {-Nitrosoanatabine } \\ \text { Nicotine MP } & \text { Nicotine Retained in the Mouthpiece of the } \\ & \text { HeatStick } \\ \text { NNK } & \text { 4-(Methylnitrosamino)-1-(3-Pyridyl)-1- } \\ & \text { Butanone } \\ \text { NNN } & N \text {-Nitrosonornicotine } \\ \text { NO; NO } & \text { Nitrogen Oxide } \\ \text { PAH } & \text { Polyaromatic Hydrocarbon } \\ \text { SR-1, }-4,-5,-6 \text { Specific Smoking Regimen } \\ \text { THS } & \text { Tobacco Heating System } \\ \text { TSNA } & \text { Tobacco-Specific Nitrosamine } \\ & \\ & \end{array}$

\section{INTRODUCTION}

Philip Morris International (PMI) has developed a heat-notburn tobacco heating system (THS 2.2) which heats HeatSticks and produces an aerosol without combustion. The system consists of a HeatStick, which comprises a tobacco plug and a filter section, and an electronic holder into which the HeatStick is inserted and subsequently heated by means of an electronically-controlled heating blade.

PMI has developed and implemented a comprehensive assessment program (https://www.pmiscience.com) to test and evaluate the ability for Reduced Risk Products (RRPs ${ }^{1}$ ) to reduce the risk of smoking-related diseases compared to continuing to smoke cigarettes. In this context, the main goal of this exploratory study was to propose and assess a simple approach for the estimation of product users' mouth level exposure (MLE) to harmful and potentially harmful constituents (HPHCs). The investigated approach was based on the analysis of nicotine in the mouthpiece (Nicotine MP) of used HeatSticks (Figure 1) that can be collected after use.

\footnotetext{
${ }^{1}$ Reduced Risk Products (RRPs) is the term we use to refer to products that present, are likely to present less risk of harm to smokers who switch to these products versus continued smoking. We have a range of RRPs in various stages of developement, scientific assessment and commercialization. Because our RRPs do not burn tobacco, they produce far lower quantities of harmful and potentially harmful compounds than found in cigarette smoke.
}

Each individual smoker is unique, therefore the variety of puffing behaviors cannot be represented by a single pattern. For this reason, the analysis of spent filters from humansmoked (HS) cigarettes has been used to estimate cigarette smokers' puffing behavior in studies already published four decades ago (1-3). Ever since, scientists have continued to use this approach, as published in more recent smoking behavior studies $(4,5)$.

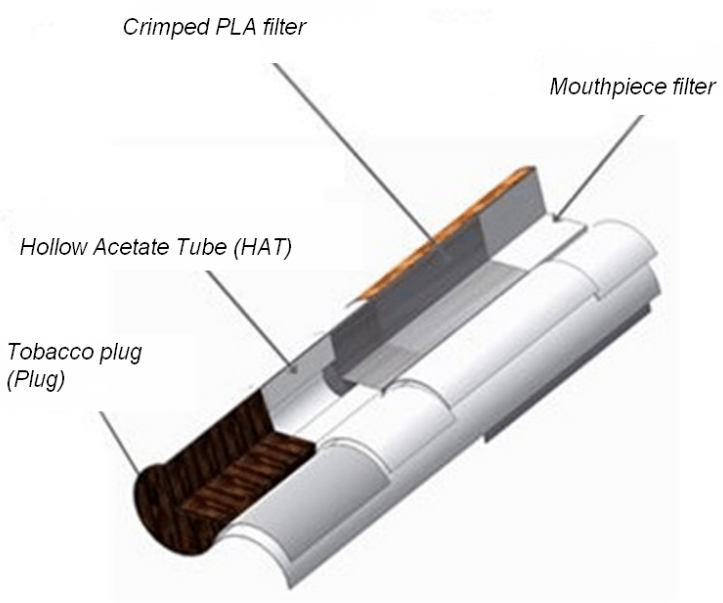

Figure 1. Design of THS HeatStick and identification of mouthpiece section used in this study. PLA, poly lactic acid.

A literature review conducted by PAULY et al. (6) highlighted the fact that all the research identified using filter based assays was performed exclusively using cigarettes with cellulose acetate filters. There were no published studies which incorporated RRPs or other smoking articles (e.g., electrically heated cigarettes). Therefore, this study presents an opportunity to fill the existing gap by verifying that puffing intensity and MLE can be estimated from the analysis of nicotine in filter parts recovered from used THS HeatSticks. It must be highlighted that the construction and functionality of the THS HeatStick is different to cigarettes in many aspects, hence methodological approaches did require some adaptation. Eventually, and provided a filterbased assay is proven as a proxy measure for MLE applicable for THS, it will enable additional studies to be performed using filters as surrogates or estimators for MLE and provide insight regarding the evolution of THS or equivalent products from a user exposure perspective. The major limitation of the MLE method is the fact that it only assesses puffing behavior in terms of puffing pattern but not pattern of inhalation. The latter, however, is decisive for deducing the actually absorbed dose of an aerosol constituent. Since the scope of this study is limited to the determination of MLE, the aspect of inhalation is not addressed.

Current models developed for the prediction of MLE as a function of nicotine measured in cigarette filters are commonly based on linear relationship. HYODO et al. (4) 
discussed relationships between mean MLE estimates and various machine-smoking yields. He quoted CLAYTON et al. (7) reporting a linear relationship between tobacco-specific nitrosamines (TSNAs) content in part-filters and TSNA yields in smoke, and between TSNA content in part-filters and nicotine content in part-filters. This led CLAYTON et al. (7) to conclude that nicotine in part-filters can be used to estimate MLE to four TSNAs. Likewise, MOLDOVEANU et al. reported MLE to carbonyl compounds (8), phenols (9), polycyclic aromatic hydrocarbons (10), benzene, and toluene (11) estimated from nicotine content in part-filters using linear regressions. A few years later, HYODO et al. (4) generated calibration curves between the yields of 47 mainstream smoke constituents and nicotine content in part-filters for 5 different cigarette brands and using 8 different smoking regimens. In all cases except one (i.e., formaldehyde), a coefficient of determination of $R^{2} \geq 0.80$ was achieved using linear regression. Based on current knowledge and due to the novelty of THS, there was no indication that an approach based on linear models would work with this product. Heat-not-burn technologies such as THS use tobacco and generate an aerosol through heating instead of combustion. This results in an important change in the kinetics for the formation and transfer of constituents into the aerosol when compared to a cigarette. Thus, presumably, the nicotine content in filters and the corresponding relationship with HPHC yields would be affected. This assumption relies on regression models reported by URBAN et al. (12) between smoke constituents and nicotine smoke yields measured in both cigarettes and the Electrically Heated Cigarette Smoking System (EHCSS). Here, linear models were used for the cigarettes whereas log-linear models were preferred for 15 out of 33 constituents measured in EHCSS aerosol. This was also discussed by ZENZEN et al. (13) mentioning that several HPHC parameter-to-nicotine relationships were better described by non-linear equations for the EHCSS. By analogy, these observations can reasonably be transposed to Nicotine MP, considering it is a function of the level of nicotine delivered by the aerosol.

Even though EHCSS and THS are different products, they are both based on the heat-not-burn tobacco principle. Thus, by analogy with EHCSS, the present study could not be limited to linear correlations for the development of models. Therefore, the approach chosen to address non-linearity was based on the use of polynomial functions.

The purpose of the study was therefore to determine and assess polynomial functions aimed at describing the relationship between 43 individual HPHCs and Nicotine MP. The aim was to generate experimental values with laboratory smoking machines using five different puffing regimens, which were selected to cover the range of anticipated product usage by users. The study was also designed to verify that the range of the Nicotine MP levels determined for human use of the product fell within the range generated by machine smoking.

\section{MATERIALS AND METHODS}

\subsection{THS product}

The Tobacco Heating System (THS) used was the THS 2.2 including associated components (i.e., HeatSticks, THS Holder and THS Pocket Charger).
The HeatSticks contained tobacco which, when heated, generated an aerosol. It was custom-designed to be used with the THS Holder. This study is limited to HeatSticks produced with a non-mentholated tobacco blend, internally identified by the non-commercial product code FR1. A single reference batch of HeatSticks was used in this study. The function of the Holder is to heat HeatSticks, delivering an aerosol to the user. The electrical heating is powered from an internal battery, which delivers power for about 6 min (allowing complete use of a single HeatStick).

The function of the THS Pocket Charger is to recharge the battery of the Holder after use. It contains a battery with sufficient capacity to recharge the Holder up to 20 times. The battery of the Pocket Charger is recharged from a main power source.

\section{STUDY DESIGN}

\subsection{Study participants}

Adult smokers of cigarettes (age: 21-60 years) with a regular daily cigarette consumption of at least 10 cigarettes with a 6-mg ISO "tar" yield were recruited for participation in the study by a consumer panel recruiting agency (RANDOM SA, Morges, Switzerland). The panelists were informed regarding the sponsor, the aims and requirements for the study, and the voluntary nature of their participation in both written and verbal form. All panelists were also informed about the possible health consequences of smoking. The panelists gave their written informed consent for their participation prior to the study commencing. Before participating in the assessments in which THS was used, panelists were allowed to familiarize themselves with the correct use of the test product under the instruction and supervision of PMI staff.

Adult THS users (age: 21-60 years) with a regular daily consumption of at least 5 HeatSticks were recruited from a PMI internal panel for participation in the study. The panelists were informed about the aims and requirements for the study, and the voluntary nature of their participation in both written and verbal form. All panelists were also informed about the possible health consequences of smoking. The panelists gave their written informed consent for their participation prior to the study commencing.

\subsection{Puffing regimen using smoking machine}

The models were constructed based on the five puffing regimens described in Table 1.

This study was initiated with limited information about user behavior and therefore required approximations based upon best assumptions of product use to define relevant smoking machine parameters. However, a retrospective comparison with an independent smoking topography study that was part of a global clinical program to assess THS was performed, which indicated that the selected puffing regimens covered the range of expected usage behaviors. The latter study was conducted in Poland in 2013 in accordance with International Conference on Harmonisation of Technical Requirements for Registration of Pharmaceuticals for Human Use (ICH) Good Clinical Practice (GCP) and was 
Table 1. Puffing regimens and accumulations of HeatSticks according to specific groups of constituents.

\begin{tabular}{l|c|c|c|c|c|c|c|c}
\hline Regimen & \multirow{2}{*}{$\begin{array}{c}\text { Puff volume } \\
(\mathrm{mL})\end{array}$} & $\begin{array}{c}\text { Puff duration } \\
(\mathrm{sec})\end{array}$ & $\begin{array}{c}\text { Puff interval } \\
(\mathrm{sec})\end{array}$ & $\begin{array}{c}\text { Number of } \\
\text { puffs }(\mathrm{n})\end{array}$ & $\begin{array}{c}\text { Nicotine and } \\
\text { CO }\end{array}$ & Carbonyls & $\mathrm{NO}_{\mathrm{x}}$ & $\begin{array}{c}\text { Other } \\
\text { HPHCs }\end{array}$ \\
\hline ISO & 35 & 2.0 & 60 & 6 & 6 & 2 & 5 & 5 \\
HCl & 55 & 2.0 & 30 & 12 & 3 & 2 & 3 & 5 \\
SR-4 & 60 & 2.4 & 25 & 14 & 3 & 2 & 3 & 5 \\
SR-6 & 80 & 2.4 & 25 & 14 & 3 & 2 & 3 & 5 \\
LR-3 & 110 & 4.5 & 22 & 14 & 2 & 2 & NA & 5 \\
\hline
\end{tabular}

Abbreviations: $\mathrm{CO}=$ carbon monoxide; $\mathrm{NA}=$ not applicable; $\mathrm{NO}_{\mathrm{x}}=$ nitrogen oxides; $\mathrm{HCl}=\mathrm{Health}$ Canada Intense; ISO = International Organization for Standardization; HPHC = harmful and potentially harmful constituent; SR-4, SR-6 and LR-3 are arbitrary names.

approved by an independent Ethic Committee registered with ClinicalTrials.gov (No. NCT01959932). Details about this investigation on puffing topography parameters for THS are accessible at https://www.pmiscience.com (14). The selection of puffing regimens was based on two standard regimens: Health Canada Intense (HCI) (17) and International Organization for Standardization (ISO) (18), plus three additional puffing regimens. It should be noted that THS is designed to operate for $365 \mathrm{sec}$ (including a $30 \mathrm{sec}$ pre-heating period) but, unlike cigarettes, duration of use cannot be defined by measurement of butt length. For this reason, ISO and HCI regimens were fixed at 6 puffs and 12 puffs, respectively. The other regimens used 14 puffs, after which the THS microcontroller automatically switched off the heating unit.

The total puffing duration for all regimens used in the models (Table 3) was at least $320 \mathrm{sec}$, including $30 \mathrm{sec}$ preheating. After $180 \mathrm{sec}$ at isothermal conditions, the temperature of the tobacco heating blade was incrementally increased to maintain favorable conditions for the formation and the release of aerosol constituents. From this perspective, using at least $320 \mathrm{sec}$ would prevent any underestimation of aerosol constituent deliveries, since a comparison with the human smoking topography (HST) study performed in Poland indicated that $75 \%$ of HeatSticks were consumed after $246.36 \mathrm{sec}$ (mean duration $200.8 \mathrm{sec}$ ) with maximum total use of duration of $323.4 \mathrm{sec}$ (see Appendix, Table 10, Day 4).

Total puff volume is the dominant factor influencing the level of aerosol constituents delivered by THS. The puff volume of $110 \mathrm{~mL}$ used with regimen LR-3 was selected as the upper limit that would be reasonably achievable by users. This upper limit was entirely consistent with HST results (see Appendix, Table 10). On the basis of a Tukey boxplot, the upper limit of the puff volume distribution was estimated as the $3^{\text {rd }}$ quartile (Q75) plus 1.5 times the interquartile range (IRQ $=$ Q75 - Q25). This highlighted that human-puffing would seldom exceed $110 \mathrm{~mL}$ since upper limits of puff distribution estimated for Day 1 and Day 4 were 104.9 and $93.0 \mathrm{~mL}$, respectively. The same approach was used to verify the relevance of the total volume. Here, the theoretical limit of the model was $1540 \mathrm{~mL}$ (i.e., 14 puffs of $110 \mathrm{~mL}$ ), which was $3 \%$ below and $7 \%$ above the upper limits estimated for the distribution of total volumes measured for Day $1(1584 \mathrm{~mL})$ and Day 4 $(1445 \mathrm{~mL})$, respectively. Therefore, the puff volume and total volume selected to define the upper limit of the models were consistent with HST. Two other regimens used in the models were based on 14 puffs of $60 \mathrm{~mL}$ (i.e., SR-4) and $80 \mathrm{~mL}$ (i.e., SR-6). The same puff duration of $2.4 \mathrm{sec}$ was used for these two regimens. The puff volume was selected such that total puff volumes accumulated with 14 puffs (i.e., $840 \mathrm{~mL}$ and $1120 \mathrm{~mL}$, respectively) were evenly distributed within the range defined by $\mathrm{HCI}$ $(660 \mathrm{~mL})$ and LR-3 $(1540 \mathrm{~mL})$.

Proportionality between Nicotine MP and nicotine yield could be anticipated provided that filtration efficiency remains constant. The total efficiency of a cigarette filter can be partitioned into contributions from condensation and particle capture (30). The particulate filtration efficiency is primarily a function of the nominal filter pressure drop and aerosol flow rate, whereas vapor efficiency is dependent upon the butt length and mainstream temperature. Considering that the mouthpiece filter is fixed by design and that the butt length of a HeatStick does not change during use, aerosol flow rate and temperature were identified as the most critical factors that could influence nicotine filtration efficiency.

Table 2. Alternative regimens.

\begin{tabular}{l|c|c|c|c|c|c|c|c}
\hline Regimen & $\begin{array}{c}\text { Puff volume } \\
(\mathrm{mL})\end{array}$ & $\begin{array}{c}\text { Puff duration } \\
(\mathrm{sec})\end{array}$ & $\begin{array}{c}\text { Puff interval } \\
(\mathrm{sec})\end{array}$ & $\begin{array}{c}\text { Number of } \\
\text { puffs }(\mathrm{n})\end{array}$ & $\begin{array}{c}\text { Nicotine and } \\
\text { CO }\end{array}$ & Carbonyls & $\mathrm{NO}_{\mathrm{x}}$ & $\begin{array}{c}\text { Other } \\
\text { HPHCs }\end{array}$ \\
\hline SR-1 & 40 & 2.4 & 30 & 8 & 6 & 2 & 3 & 5 \\
SR-5 & 80 & 2.4 & 30 & 8 & 3 & 2 & 3 & 5 \\
\hline
\end{tabular}

Abbreviations: $\mathrm{CO}=$ carbon monoxide; $\mathrm{NO}_{\mathrm{x}}=$ nitrogen oxides; HPHC = harmful and potentially harmful constituent; SR-1 and SR-5 are arbitrary names. 
Table 3. Mean puff flow rates and total puffing duration according to puffing regimens.

\begin{tabular}{lcc}
\hline Regimen & Puff flow rate $(\mathrm{mL} / \mathrm{sec})$ & Total puffing duration $(\mathrm{sec})$ \\
\hline SR-1 & 16.7 & 242 \\
ISO & 17.5 & 332 \\
LR-3 & 24.4 & 321 \\
SR-4 & 25.0 & 357 \\
HCI & 27.5 & 362 \\
SR-5 & 33.3 & 242 \\
SR-6 & 33.3 & 357 \\
\end{tabular}

Abbreviations: $\mathrm{HCl}=$ Health Canada Intense; ISO = International Organization for Standardization; SR-1, SR-4, SR-5, SR-6 and LR-3 are arbitrary names.

The impact of THS temperature evolution on the kinetics of formation and transfer for other aerosol constituents was also anticipated. Therefore, a verification test was included using two additional regimens (i.e., SR-1 and SR-5) with abbreviated puffing duration (i.e., $242 \mathrm{sec}$ ) that were also combined with a reduced number of puffs (i.e., 8 puffs). The range of mean puff flows covered by machine-smoking regimens (Table 3 ) were consistent with HST values (see Appendix, Table 10). The mean puff flows for LR-3, HCI, SR-4, SR-5 and SR-6 regimens were distributed within a range starting slightly below the median HST values measured on Day 1 and Day 4 (i.e., $25.40 \mathrm{~mL} / \mathrm{sec}$ and $26.32 \mathrm{~mL} / \mathrm{sec}$, respectively) to just above the $3^{\text {rd }}$ quartile (i.e., $31.10 \mathrm{~mL} / \mathrm{sec}$ and $32.44 \mathrm{~mL} / \mathrm{sec}$, respectively). Mean puff flows used with ISO and SR-1 regimens were in the low range lying below the $1^{\text {st }}$ quartile measured for both HST days.

The intended role of these abbreviated puffing regimens (i.e., SR-1 and SR-5) was to explore the possibility for model deviations related to specific kinetics of formation and transfer for individual constituents. Data from all puffing regimens were used to define the relationship between Nicotine MP and aerosol nicotine yield, in order to account for the influence of abbreviated use, where lower temperature conditions prevailed.

HST showed product usage exceeding 14 puffs (i.e., $3^{\text {rd }}$ quartile at 17.90 and 17.00 for Day 1 and Day 4 respectively). However, machine-smoking was limited to a maximum of 14 puffs according to the actual device operating conditions.

\subsection{Collection and analysis of mouthpieces from panels of smokers using THS}

Volunteers that regularly use THS HeatSticks or smokers of cigarettes were invited to participate in two different campaigns organized for the collection of mouthpieces from spent THS HeatSticks. The mouthpieces were collected and analyzed at different times and were independent from the machine-smoking experiments presented in this study.

In the first trial, a total of 21 adult volunteers were recruited from an internal panel of smokers that regularly used THS and that consumed at least five HeatSticks per day. They were invited to use THS ad libitum and were asked to collect at least five mouthpieces per day for five days. The volunteers were not maintained in confinement and were free to use other tobacco products ad libitum. A pool of five mouthpieces was picked randomly from each day of collection for each volunteer. Each pool was extracted and analyzed for the determination of Nicotine MP. When the expected number of mouthpieces was not available, pools containing less than five mouthpieces were analyzed and the extraction volume was adapted accordingly (i.e., $5 \mathrm{~mL} /$ mouthpiece). In the second trial, a total of 12 adult volunteers were recruited to use THS under controlled experimental conditions and were invited to use the product in a room over a 5 -h period with a specified frequency of use. Using other tobacco products was not permitted. A total of 163 mouthpieces were collected and each piece was analyzed individually (not pooled).

\subsection{Machine-smoking aerosol generation}

The room conditions for aerosol generation were maintained at $22 \pm 2{ }^{\circ} \mathrm{C}$ and $60 \pm 5 \%$ relative humidity.

The HeatSticks were stored in a cooling chamber at $5 \pm 3{ }^{\circ} \mathrm{C}$ in their original packaging. Prior to the analysis the HeatSticks were prepared and conditioned according to ISO 3402 (15).

Aerosol generation was performed using a Borgwaldt linear smoking machine type LM20X (Northern Chesterfield, Richmond, VA, USA).

The generated aerosols were trapped and subsequently treated (e.g., derivatized or cleaned) and analyzed according to the methods described in the following chapters. The conversion from primary result to a value per HeatStick was based on the number of accumulations, the trapping or extraction volume and taking any dilution into account.

The aerosol constituents were analyzed on the basis of 5 replicates for each tested regimen. In some cases more replicates were generated to verify the consistency of results. These verifications were limited to specific constituents and regimens and were used for the construction of models. Each sample replicate resulted from the collection of aerosol accumulated from several HeatSticks. The subsequent analytical results were reported on a per stick basis. The number of accumulations used for each replicate was dependent upon the puffing regimen and/or the group of constituents according to conditions specified in Table 1.

The assessment for the correlation between aerosol nicotine yield and Nicotine MP included two additional regimens (Table 2) and was based on a minimum of 10 measurements combining series of 4 to 5 replicates analyzed over various days for each tested regimen.

\subsection{Aerosol analysis}

The methods used for the analysis of aerosol constituents were either developed internally or recommended by the Cooperation Centre for Scientific Research Relative to Tobacco (CORESTA) as CRM (CORESTA Recommended Method), the International Organization for Standardization (ISO) or the Federal Health Canada department (HC). 
3.5.1 Analysis of ISO parameters (according to ISO 4387 (16), 8454 (18) and 10315 (19))

The aerosol was collected on a Cambridge glass fiber filter pad ( $\varnothing 44 \mathrm{~mm}$ ) connected in series to a carbon monoxide (CO) meter (Borgwaldt $\mathrm{CO} / \mathrm{CO}_{2}$ Analyzer $\mathrm{C} 25$, North Chesterfield, Richmond, VA, USA). CO was determined without further treatment using the $\mathrm{CO}$ analyzer connected to the Borgwaldt LM20X smoking machine, conforming to ISO standard 8454, using non-dispersive infrared photometry.

For nicotine determination, the filter pads were extracted with $10 \mathrm{~mL}$ isopropanol containing the internal standard (n-heptadecane).

Nicotine was analyzed by isothermal gas chromatography (GC) at $170{ }^{\circ} \mathrm{C}$ using flame ionization detection (FID) at $250{ }^{\circ} \mathrm{C}$. A gas chromatograph (Thermo Electron S.p.A., Rodano, Italy) equipped with a computerized data station (Chromcard software), a hydrogen generator (NMH2 160, Linde Gases Division, Pullach, Germany), an autosampler (CTC Analytics, Zwingen, Switzerland), a 7\% Carbowax 20M, 3\% polyphenylether OS 138 and $2 \% \mathrm{KOH}$ column $(4 \mathrm{ft} \times$ ED 1/8" × ID $2.0 \mathrm{~mm}$; Restek, Bellefonte, PA, USA) was used. Nicotine content was calculated based on linear regression of a 5-point calibration curve.

3.5.2 Analysis of volatiles and semi-volatiles (1,3-butadiene, acrylonitrile, benzene, isoprene, and toluene according to CRM 70 (20); quinoline, pyridine, styrene according to HC T-112 (21))

The aerosol was collected using a Cambridge glass fiber filter pad ( $\varnothing 44 \mathrm{~mm}$ ) connected in series with a first micro impinger cooled at $0{ }^{\circ} \mathrm{C}$ and a second micro impinger cooled at $-70{ }^{\circ} \mathrm{C}$, each containing $10 \mathrm{~mL}$ methanol. The contents of the two micro impingers were pooled and combined with the filter pad. The extracts were analyzed by GC using mass spectrometry (MS) detection with electron ionization (EI). The extracts were analyzed twice using two different temperature programs. For volatiles (1,3-butadiene, isoprene, benzene, acrylonitrile and toluene) the extracts were injected using split mode and the column was held for $2.5 \mathrm{~min}$ at $40{ }^{\circ} \mathrm{C}$, ramped to $240{ }^{\circ} \mathrm{C}$ at a rate of $30^{\circ} \mathrm{C} / \mathrm{min}$ and held for $13.0 \mathrm{~min}$. For semi-volatiles (pyridine, styrene and quinoline) the extracts were injected using splitless mode and the column was held for $2.0 \mathrm{~min}$ at $40^{\circ} \mathrm{C}$, ramped to $150^{\circ} \mathrm{C}$ at a rate of $10^{\circ} \mathrm{C} / \mathrm{min}$, ramped to $240{ }^{\circ} \mathrm{C}$ at a rate of $20^{\circ} \mathrm{C} / \mathrm{min}$ and held for $20 \mathrm{~min}$. A gas chromatograph-mass spectrometer (Shimadzu QP-2010 Plus, Shimadzu Corp., Kyoto, Japan) equipped with a computerized data station (GCMS solution software, Shimadzu, Kyoto, Japan) for data acquisition and processing, a deactivated fused silica guard column, $2 \mathrm{~m}$ of $0.25 \mathrm{~mm}$ ID and an Agilent J\&W DBWAX-ETR (Agilent Technologies Inc., Santa Clara, CA, USA), $30 \mathrm{~m} \times 0.25 \mathrm{~mm}$ ID, $0.5 \mu \mathrm{m}$ film thickness capillary column were used. The concentrations of the 8 analyzed volatiles and semi-volatiles were calculated based on linear regression of 6 point calibration curves prepared with 1,3-butadiene-d6, benzene-d6, acrylonitrile-d3, toluene-d8, pyridine-d5, styrene-d8 and quinoline-d7 as internal standards.

\subsubsection{Analysis of carbonyls (internal method based on} modified CRM 74 (22))

The aerosol was collected using three micro impingers, each containing $10 \mathrm{~mL}$ 2,4-dinitrophenylhydrazine (DNPH 50\% water content, puriss from Sigma-Aldrich, St. Louis, MO, USA) connected in series to the smoking machine. The extracts were analyzed by gradient elution liquid chromatography (LC) with starting conditions $80 \%$ mobile phase A (water/acetonitrile/isopropanol/tetrahydrofuran (59:30:1:10 $(\mathrm{v} / \mathrm{v} / \mathrm{v} / \mathrm{v})$ ) and $20 \%$ mobile phase B (acetonitrile) held for 7.5 min before mobile phase B was ramped to $98 \%$ in $0.5 \mathrm{~min}$ and held for $2 \mathrm{~min}$. Detection was performed using tandem mass spectrometry (MS/MS) with an atmospheric pressure chemical ionization (APCI) interface in negative ionization mode. An LC-MS/MS comprising a Flux Instruments Rheos 2200 pump (Conquer Scientific, San Diego, CA, USA), a CTC PAL HTC auto injector, a Thermo Finnigan TSQ Quantum Discovery MS/MS detector, a computerized data station (Xcalibur software) for data acquisition and processing (ThermoFisher Scientific Inc., Waltham, MA, USA) was used. A Phenomenex Security Guard Cartridge (Phenomenex International, Torrance, CA, USA) and a Shiseido Capcell PAK C18 MG $5 \mu \mathrm{m}, 150 \mathrm{~mm} \times 2.1 \mathrm{~mm}$ analytical column (Shiseido Group, Tokyo, Japan) were used. The concentrations of acetaldehyde, acetone, acrolein, butyraldehyde, crotonaldehyde, formaldehyde, methyl ethyl ketone (MEK), and propionaldehyde were calculated based on linear regression of 7 point calibration curves prepared with acetone-d6 as internal standard (for acetaldehyde a quadratic regression was applied).

\subsubsection{Analysis of aromatic amines (internal method based on HC T-102 (23), modified for the determination of o-toluidine)}

The aerosol was collected on a Cambridge glass fiber filter pad ( $\varnothing 44 \mathrm{~mm})$. The filter pad was extracted with a hydrochloric acid solution $(0.21 \mathrm{M})$ which was then filtered, basified and further cleaned up and trace-enriched using automated solid phase extraction (SPE). The eluent was derivatized with heptafluorobutyric anhydride (HFBA) and analyzed by GC-MS in negative chemical ionization mode (NCI) using the following temperature program; $80^{\circ} \mathrm{C}$ for $2.0 \mathrm{~min}$, ramped to $220^{\circ} \mathrm{C}$ at a rate of $10^{\circ} \mathrm{C} / \mathrm{min}$, ramped to $325{ }^{\circ} \mathrm{C}$ at a rate of $40{ }^{\circ} \mathrm{C} / \mathrm{min}$ and held for $5.0 \mathrm{~min}$. A GC-MS (Shimadzu QP-2010) equipped with a computerized data station (GCMS solution software) for data acquisition and processing and an Agilent J\&W DB-5MS column, $30 \mathrm{~m} \times 0.25 \mathrm{~mm}$ ID, $0.25 \mu \mathrm{m}$ film thickness) was used. The concentrations of 1-aminonaphthalene, 2-aminonaphthalene, 3-aminobiphenyl, 4-aminobiphenyl and $o$-toluidine were calculated based on linear regression of 7 points calibration curves prepared with 1-amino-naphthalene-d7, 2-aminonaphthalene-d7, 4-aminobiphenyl-d9 and $o$-toluidine-d9 as internal standards.

\subsubsection{Analysis of nitrogen oxides $\left(\mathrm{NO}_{x}\right.$ ) (according to $\mathrm{HC}$} T-110 (24))

The aerosol was collected in a gas collection bag connected to a Borgwaldt linear smoking machine. The concentration 
of nitrogen oxide $(\mathrm{NO})$ and nitrogen oxides $\left(\mathrm{NO}_{\mathrm{x}}\right)$ in the gas of the collection bag was analyzed directly after aerosol generation using a chemiluminescence detector system (Eco Analytics CLD 844 NO meter; Eco Analytics, Rheinfelden, Switzerland) calibrated with 80 ppm NO certified reference gas (Messer Schweiz AG, Lenzburg, Switzerland).

\subsubsection{Analysis of ammonia (internal method based on modified CRM 79 (25))}

The aerosol was collected on a Cambridge glass fiber filter pad ( $\varnothing 44 \mathrm{~mm}$ ) connected in series with two micro impingers each containing $10 \mathrm{~mL}$ hydrochloric acid $(0.005 \mathrm{M})$. The contents of the two micro impingers were pooled and combined with the filter pad. The extracts were derivatized with dansyl chloride (DNS) and analyzed by isocratic (acetonitrile/water (70/30 (v/v)) LC-MS/MS with an atmospheric pressure chemical ionization (APCI) interface in positive ionization mode. An LC-MS/MS system comprising a Flux Instruments Rheos 2000 pump, a CTC PAL HTC auto injector, a Thermo Finnigan TSQ Quantum Discovery MS/MS detector, a computerized data station (Xcalibur software) for data acquisition and processing and an Agilent Zorbax SB C-18 analytical column, $150 \mathrm{~m} \times 3 \mathrm{~mm}, 3.5 \mu \mathrm{m}$, was used. The concentration of ammonia was calculated based on linear regression of a 7 point calibration curve prepared with ammonium- $-{ }^{15} \mathrm{~N}, \mathrm{~d}_{4}$ chloride as internal standard.

\subsubsection{Analysis of epoxides and vinyl chloride (internal method)}

The aerosol was collected using a Cambridge glass fiber filter pad $(\varnothing 44 \mathrm{~mm})$ connected in series with a single micro impinger containing $10 \mathrm{~mL}$ toluene at $-70^{\circ} \mathrm{C}$. The pad was discarded.

For the analysis of ethylene oxide and vinyl chloride, GCMS in selective ion monitoring (SIM) mode was used with the following temperature program; $45{ }^{\circ} \mathrm{C}$ for $1.0 \mathrm{~min}$, ramped to $105^{\circ} \mathrm{C}$ at a rate of $3{ }^{\circ} \mathrm{C} / \mathrm{min}$, ramped to $135^{\circ} \mathrm{C}$ at a rate of $20^{\circ} \mathrm{C} / \mathrm{min}$, held for $5.0 \mathrm{~min}$ at $135^{\circ} \mathrm{C}$, ramped to $190{ }^{\circ} \mathrm{C}$ at a rate of $30^{\circ} \mathrm{C} / \mathrm{min}$ and held for $15.0 \mathrm{~min}$. A GC-MS (Agilent 7890N GC with 5975B mass selective detector (MSD)) equipped with a split/splitless injector used in splitless mode, a 7683 autosampler, a computerized data station (MassHunter software) for data acquisition and processing and an AgilentVarian PoraPlot-U column ( $25 \mathrm{~m} \times 0.25 \mathrm{~mm}$ ID, $8 \mu \mathrm{m}$ film thickness) was used. The concentrations were calculated based on linear regression of 7-point calibration curves prepared with propylene oxide-d6 as internal standard for both compounds.

\subsubsection{Analysis of tobacco-specific nitrosamines (TSNAs) (internal method based on modified CRM 75 (26))}

The aerosol was collected on a Cambridge glass fiber filter pad $(\varnothing 44 \mathrm{~mm})$. The filter pad was extracted with $10 \mathrm{~mL}$ ammonium acetate solution $(100 \mathrm{mmol} / \mathrm{L})$ containing $N$ nitrosonornicotine-d4 (NNN-d4) and 4-(methylnitrosamino)-1-(3-pyridyl-d4)-1-butanone (NNK-d4) as internal standards. After filtration, an aliquot of the extract was analyzed by gradient elution LC with starting conditions $90 \%$ mobile phase $\mathrm{A}$ (water) and $10 \%$ mobile phase $\mathrm{B}(0.1 \%(\mathrm{v} / \mathrm{v})$ formic acid in methanol), ramped to $30 \% \mathrm{~B}$ $(70 \% \mathrm{~A})$ in $4 \mathrm{~min}$, ramped to $100 \% \mathrm{~B}(0 \% \mathrm{~A})$ in $2 \mathrm{~min}$ and held for $1 \mathrm{~min}$ at $100 \% \mathrm{~B}$. Detection was performed using MS/MS with electrospray ionization (ESI) in positive ionization mode. An LC-MS/MS system comprising a Flux Instruments Rheos 2000 pump, a CTC PAL HTC auto injector, a Thermo Finnigan TSQ Quantum Discovery MSMS detector, a computerized data station (Xcalibur software) for data acquisition and processing (ThermoFisher Scientific Inc.) was used. A Waters Symmetry C18 $5 \mathrm{~m}$ guard column (Waters Corporation, Milford, MS, USA) and a Supelco Discovery HS-C18, $3 \mu \mathrm{m}, 50$ x $2.1 \mathrm{~mm}$ ID analytical column plus (Sigma-Aldrich Supelco) were used. The concentrations of 4-(methylnitrosamino)-1-(3-pyridyl)1-butanone (NNK), $N$-nitrosoanabasine (NAB), $N$-nitrosoanatabine (NAT) and $N$-nitrosonornicotine (NNN) were calculated based on linear regression of 6 point calibration curves prepared with $\mathrm{NNN}-\mathrm{d} 4$ and $\mathrm{NNK}-\mathrm{d} 4$ as internal standards.

\subsubsection{Analysis of phenols, acrylamide and acetamide (internal method)}

The aerosol was collected on a Cambridge glass fiber filter pad $(\varnothing 44 \mathrm{~mm})$ connected in series with a single cooled micro impinger $\left(0{ }^{\circ} \mathrm{C}\right)$ containing phenol-d6, catechol-d6 and hydroquinone-d6 as internal standards in $10 \mathrm{~mL}$ butanone. The filter pad was extracted with the contents of the micro impinger. The extracts were analyzed separately for phenols and for acrylamide and acetamide.

For phenols, the extracts were derivatized with $\mathrm{N}, \mathrm{O}$ bis(trimethylsilyl)-trifluoracetamide with $1 \%$ trimethylchloro-silane (BSFTA 1\% TMCS from Sigma-Aldrich, St. Louis, MO, USA) and analyzed by GC-MS in EI mode using the following temperature program; $50{ }^{\circ} \mathrm{C}$ for $2.0 \mathrm{~min}$, ramped to $130^{\circ} \mathrm{C}$ at a rate of $20^{\circ} \mathrm{C} / \mathrm{min}$, ramped to $200^{\circ} \mathrm{C}$ at a rate of $10{ }^{\circ} \mathrm{C} / \mathrm{min}$, ramped to $225^{\circ} \mathrm{C}$ at a rate of $25^{\circ} \mathrm{C} / \mathrm{min}$ and held for $10.0 \mathrm{~min}$. A GC-MS (Shimadzu QP-2010, Shimadzu Corp., Kyoto, Japan) equipped with a computerized data station (GCMS solution software) for data acquisition and processing and an Agilent J\&W DB624 column $(30 \mathrm{~m} \times 0.32 \mathrm{~mm}$ ID, $1.8 \mu \mathrm{m}$ film thickness $)$ was used. The concentrations of catechol, hydroquinone, meta-cresol ( $m$-cresol), ortho-cresol ( $o$-cresol), para-cresol ( $p$-cresol), phenol and resorcinol were calculated based on linear regression of 7-point calibration curves prepared with phenol-d6, catechol-d6 and hydroquinone-d6 as internal standards.

Acrylamide and acetamide were analyzed by GC-MS in EI mode without derivatization using the following temperature program; $40{ }^{\circ} \mathrm{C}$ for $2.0 \mathrm{~min}$, ramped to $200^{\circ} \mathrm{C}$ at a rate of $10^{\circ} \mathrm{C} / \mathrm{min}$, ramped to $250{ }^{\circ} \mathrm{C}$ at a rate of $25^{\circ} \mathrm{C} / \mathrm{min}$ and held for $1.0 \mathrm{~min}$, including a post run for $10 \mathrm{~min}$ at $250^{\circ} \mathrm{C}$ and $2.0 \mathrm{~mL} / \mathrm{min}$. A GC-MS (Agilent Technologies Inc. 7890A with 5975C MSD) equipped with a split/splitless injector, a computerized data station (MassHunter software) for data acquisition and processing and an Agilent $\mathrm{J} \& \mathrm{~W}$ DB-FFAP column $(30 \mathrm{~m} \times 0.25 \mathrm{~mm}$ ID, $0.25 \mu \mathrm{m}$ film thickness) was used with a $2 \mathrm{~m}$ pre-column DB-FFAP $0.25 \mathrm{~mm}$ ID, $0.25 \mu \mathrm{m}$. The concentrations of acrylamide 
and acetamide were calculated based on linear regression of 8-point calibration curves prepared with phenol-d6 as internal standard.

\subsubsection{Analysis of polyaromatic hydrocarbons (PAHs) (internal method based on ISO 22634 (27) for the determination of benzo[a]pyrene and modified for the determination of additional PAHs)}

The aerosol was collected on a Cambridge glass fiber filter pad $(\varnothing 44 \mathrm{~mm})$. The pad was extracted with hexane and the PAHs concentrated by means of sequential SPE steps $\left(\mathrm{NH}_{2}\right.$ and $\mathrm{C}-18$ phases). The final extract in isooctanol was analyzed by GC-MS in SIM mode using pulsed splitless injection and the following temperature program: $10^{\circ} \mathrm{C}$ for $1.0 \mathrm{~min}$, ramped to $260^{\circ} \mathrm{C}$ at a rate of $12{ }^{\circ} \mathrm{C} / \mathrm{min}$, ramped to $330^{\circ} \mathrm{C}$ at a rate of $20^{\circ} \mathrm{C} / \mathrm{min}$ and held for $10.0 \mathrm{~min}$. A GC-MS (Agilent 7890A with 5975C MSD, Agilent Technologies Inc, Santa Clara, CA, USA) equipped with a split/splitless injector, a computerized data station (GCMSD data analysis software) for data acquisition and processing and an Agilent J\&W DB-17MS column (30 $\mathrm{m} \times 0.25 \mathrm{~mm}$ ID, $0.15 \mu \mathrm{m}$ film thickness) was used. The concentrations of benzo $[a]$ pyrene, benz $[a]$ anthracene, dibenz $[a, h]$ anthracene and pyrene, were calculated based on linear regression of 7 point calibration curves prepared with benzo $[a]$ pyrene-d 12 , benz $[a]$ anthracene-d12, dibenz$[a, h]$ anthracene-d14 and pyrene-d10 as internal standards.

\subsubsection{Filter analysis (internal method based on modified CRM 9 (28))}

The mouthpiece of the HeatStick (Figure 1) consists of a paper wrapped plug of acetate tow, $10 \mathrm{~mm}$ in length, overlaid by tipping paper. The mouthpiece section was detached from the rest of the product after use for subsequent nicotine content determination. Mouthpieces accumulated for each replicate, either pooled or individually, were extracted for $1 \mathrm{~h}$ in methanol solution containing $1 \mathrm{~g} / \mathrm{L} \mathrm{NaOH}$ and $\mathrm{n}$-heptadecane as internal standard. An extraction volume of $5 \mathrm{~mL} / \mathrm{mouthpiece}$ was used. Nicotine extract concentrations were determined by GC-FID and results calculated in terms of $\mathrm{mg}$ nicotine/mouthpiece.

An aliquot $(1 \mu \mathrm{L})$ of nicotine extract was injected onto a GC using an injector in split mode (split ratio 1:20) at $250{ }^{\circ} \mathrm{C}$ and analyzed using the following temperature program: $140{ }^{\circ} \mathrm{C}$ for $7.0 \mathrm{~min}$, ramped to $220^{\circ} \mathrm{C}$ at a rate of $30^{\circ} \mathrm{C} / \mathrm{min}$ and then held for $1.0 \mathrm{~min}$. A GC (Thermo Trace GC Ultra) equipped with a split/splitless injector, a Restek DB-Stabilwax column $(15 \mathrm{~m} \times 0.32 \mathrm{~mm}$ ID, $0.25 \mu \mathrm{m}$ film thickness) and an FID detector maintained at $250{ }^{\circ} \mathrm{C}$. A computerized data station (Xcalibur software) and an autosampler (CTC Analytics PAL) system were used. The concentration of nicotine was calculated based on linear regression of a 6-point calibration curve prepared with internal standard (n-heptadecane).

\subsubsection{Filter handling}

The filter mouthpieces from smoking machine experiments were separated from the HeatSticks directly after aerosol generation and stored at $-20^{\circ} \mathrm{C}$ in amber glass flasks used for their extraction. Panelists also collected mouthpieces separated from used HeatSticks in amber glass flasks. The samples were collected every day and stored at $-20^{\circ} \mathrm{C}$. The extraction of stored samples for subsequent nicotine analysis was conducted within a maximum of one week after collection. The samples were proven to be stable for at least two weeks under these conditions.

\section{STATISTICAL ANALYSIS}

Regression analysis was used for investigating and modeling the relationship between each aerosol constituent and Nicotine MP. The models integrated the results determined for five different puffing regimens.

\subsection{Model selection}

The REG Procedure, a general-purpose procedure for regression within the SAS System (SAS Institute Inc., Cary, NC, USA), was used to generate multiple linear regression (MLR) reports using a stepwise approach for model selection. Stepwise regression is an approach that allows the selection of a subset of effects for a regression model by interactively exploring which predictors provide a good fit, in order to improve the model's prediction performance by reducing the variance caused by estimating unnecessary terms. The level of significance for a regression term to be considered for the model was set at 0.05 , and to remain within the model set at 0.15 . Linear, quadratic, and cubic polynomial functions, using Nicotine MP as an independent variable, were identified as possible regression terms for the model, and were subsequently selected according to defined criteria.

For values determined to be below the limit of detection (LOD), the LOD value was used in the calculation. Values above the LOD, but below the lower limit of quantification (LLOQ), the LLOQ value was used in the calculation.

\subsection{Adjusted R-square}

$\mathrm{R}$-squared $\left(\mathrm{R}^{2}\right)$ indicates the closeness of fit for the data to the fitted regression line, with higher values indicating a better fit. $\mathrm{R}^{2}$ values tend to increase with the number of factors included in the model, hence adjusted R-squared $\left(\mathrm{R}^{2}\right.$ adj.) was used to penalize this effect, since this coefficient only increases if an additional term improves the model by more than would be expected by chance. The comparison between models therefore relied on adjusted R-squared values. Adjusted R-squared values can be negative (usually not), but are always lower than R-squared values.

\section{RESULTS}

\subsection{Assessing relationship between nicotine aerosol yield and Nicotine MP}

The development of HPHC-to-Nicotine MP calibration curves was based on the underlying assumptions that a) correlations exist between aerosol constituents and aerosol nicotine yields and $b$ ) a correlation exists between aerosol 
nicotine and Nicotine MP.

The coefficient of determination $\left(\mathrm{R}^{2}=0.940\right)$ calculated from means reported in Table 4 indicates a linear fit between the levels of nicotine yield and Nicotine MP (Figure 2). As a result, the development of calibration curves for other aerosol constituents was justified. However, it can be seen from the regression that there were some substantial deviations of actual data points from the estimated means. This variability could partly be attributed to the influence of flow rate and temperature on the retention of nicotine in the filter mouthpiece. The day to day variability of nicotine determination in filters is also to take into account considering that series of replicates were analyzed over various days for each tested regimen.

The mean levels of Nicotine MP measured under ISO and LR-3 regimens (Table 4, ISO $=0.12 \mathrm{mg} /$ HeatStick, LR-3 = $0.49 \mathrm{mg} /$ HeatStick) define the respective lower and upper limits for which the regression model is applicable. Beyond these limits the uncertainty for extrapolated values cannot be defined. For this reason it was important to verify that the range of Nicotine MP values obtained with machinesmoking experiments fully encompassed the range anticipated for human-smoking conditions.

Table 4. Nicotine yield and Nicotine MP under various puffing regimens.

\begin{tabular}{l|c|c|c}
\hline Regimen & $\mathrm{n}$ & $\begin{array}{c}\text { Nicotine mean } \pm \mathrm{SD} \\
(\mathrm{mg} / \text { HeatStick })\end{array}$ & $\begin{array}{c}\text { Nicotine MP mean } \pm \text { SD } \\
(\mathrm{mg} / \text { HeatStick })\end{array}$ \\
\hline ISO & 13 & $0.49 \pm 0.04$ & $0.12 \pm 0.01$ \\
SR-1 & 15 & $0.76 \pm 0.09$ & $0.20 \pm 0.02$ \\
SR-5 & 10 & $1.13 \pm 0.05$ & $0.29 \pm 0.08$ \\
HCl & 20 & $1.36 \pm 0.09$ & $0.26 \pm 0.03$ \\
SR-4 & 15 & $1.64 \pm 0.10$ & $0.32 \pm 0.05$ \\
SR-6 & 14 & $1.80 \pm 0.19$ & $0.38 \pm 0.03$ \\
LR-3 & 15 & $2.19 \pm 0.20$ & $0.49 \pm 0.09$ \\
\hline
\end{tabular}

Abbreviations: $\mathrm{HCl}=$ Health Canada Intense; ISO = International Organization for Standardization; Nicotine MP = nicotine retained in the mouthpiece of the HeatStick; SR-1, SR-5, SR-4, SR-6, and LR-3 are arbritary names.

\subsection{Verification of consistency between machine-smoking and human-smoking ranges}

Samples collected from the panels of THS users indicated that the normality of the Nicotine MP distribution was rejected by the Kolmogorov-Smirnov test $(\alpha=0.1)$. Nevertheless, a Goodness-of-Fit test showed that a lognormal distribution was a better fit.

Based on a lognormal model of distribution, only $1 \%$ of the measured Nicotine MP values for the unconfined panel population fell outside the machine-smoked range of between 0.12 and $0.49 \mathrm{mg} /$ HeatStick (Figure $3 \mathrm{~A}$ ). This confirmed that the puffing regimens selected for the model definition adequately covered the range for human users. This was also confirmed by the samples collected from confined THS users, which showed only $2 \%$ of the Nicotine MP values falling outside this range (Figure $3 \mathrm{~B}$ ).

The significant difference in Nicotine MP levels (KruskalWallis test $p$-value $<0.0001$ ) between the unconfined and

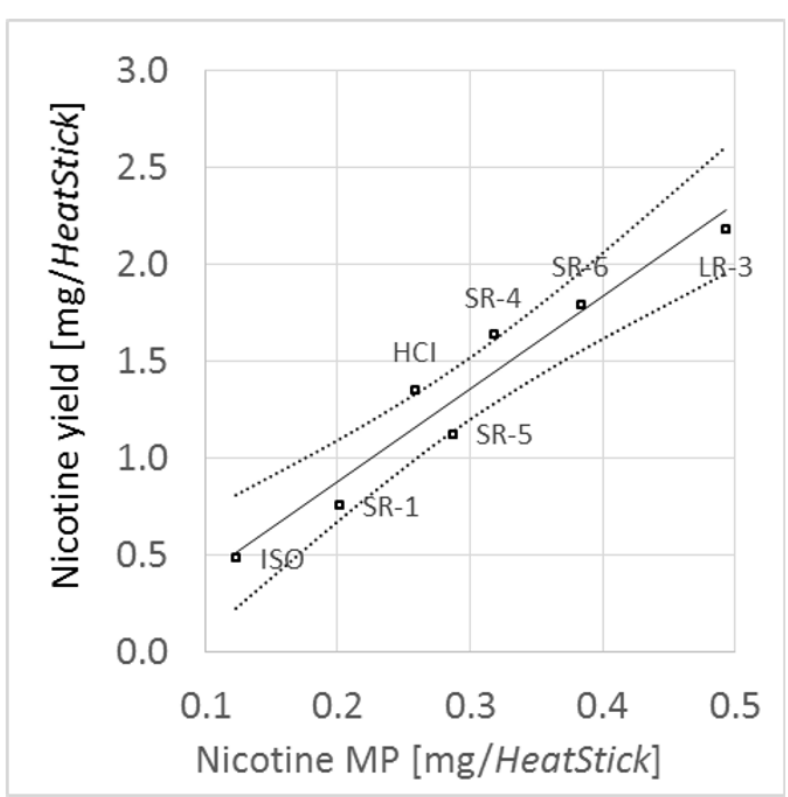

Figure 2. Relationship between nicotine aerosol yield and Nicotine MP. Continuous line is the linear regression fit between nicotine yield and Nicotine MP. Dotted lines are the 95\% confidence intervals for the estimated mean. Black squares represent the actual mean values reported in Table 4.

the confined population of THS users should be highlighted. This was attributed to the difference between the two experimental conditions.

\subsection{Calculation of individual calibration curves between Nicotine MP and 43 HPHCs}

As shown in Table 5, a large majority of models defined for the constituents considered had $\mathrm{R}^{2}$ adj. values greater than 0.75 .

The SAS REG procedure proposed a linear model for five aerosol constituents (i.e., ammonia, acrylamide, acrylonitrile, ethylene oxide, and formaldehyde). Non-linear models based on two regression parameters (including intercept) were selected for four constituents in the group of phenols (i.e., phenol, $m$-cresol, $o$-cresol, $p$-cresol) and quinoline. Non-linear models with three or four regression parameters were proposed for the rest of the constituents, which could be split into two distinct groups. The first group included aerosol constituents (i.e., acetamide, acrolein, and crotonaldehyde) that demonstrated a good fit with a linear model, despite the fact that non-linear models were selected by the SAS REG procedure. Since a linear model could be reasonably used for the calculation of calibration curves for these constituents, the regression parameters were recalculated by limiting the choice of SAS REG procedure to a linear model (Table 6).

In contrast, more regression parameters were justified for the second group of aerosol constituents due to the complex patterns of the curves (i.e., "plateau and hill" effects presented in Figure 6) principally observed within the range of Nicotine MP levels between $0.26 \mathrm{mg} /$ HeatStick and $0.49 \mathrm{mg} /$ HeatStick. Another group of 15 aerosol consti- 


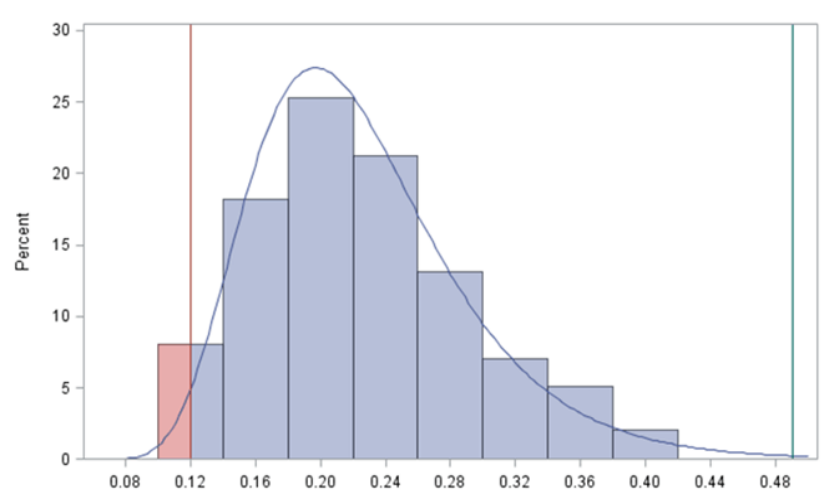

A

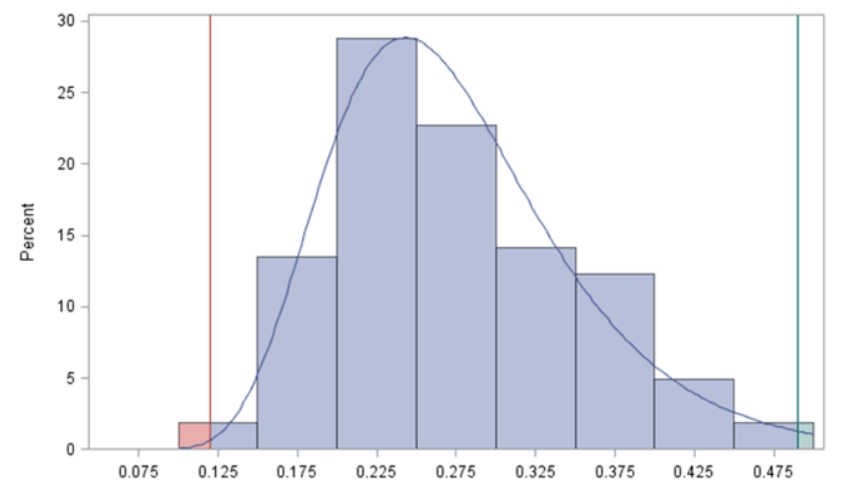

B

Figure 3. Distribution frequency for Nicotine MP [mg/HeatStick] observed for the unconfined (A) and confined (B) panel of THS users. Bars are actual values and continuous lines are estimated from model distribution frequency. The left and right vertical lines are the Nicotine MP values determined respectively under ISO (0.12 mg/HeatStick) and under LR-3 (0.49 mg/HeatStick) puffing regimens.

tuents showed $\mathrm{R}^{2}$ adj. values below 0.75 (Table 7). The case for $o$-toluidine was explained by the strong influence of a single and extreme data point that by exclusion would raise the calculated $\mathrm{R}^{2}$ adj. value to 0.877 . For isoprene, $\mathrm{NAB}$ and $\mathrm{CO}$, the low coefficient of determinations were attributed to the absence of discrimination of constituent levels between all regimens. Same observation for the remainder of the constituents reported in Table 7 that had values close to their respective LLOQs. In a first group of HPHCs (Table 8), values were below their respective LLOQ which was independent of the puffing conditions. A second group of HPHCs was characterized by an absence of any correlation $\left(\mathrm{R}^{2} \mathrm{adj} .=\right.$ 0 , Table 9). Regardless styrene and toluene that showed $\mathrm{R}^{2}$ adj. values short below 0.75 and $o$-toluidine that was influenced by one outlying value, the methodology was found unsuitable for 12 aerosol constituents that showed $\mathrm{R}^{2}$ adj. values below 0.51 due to the absence of discrimination between regimens. Here, the use of a single constant value would be recommended as a best estimate of aerosol constituent level. However, the definition of any such constant was not within the scope of this investigation and was not addressed.

\subsection{Abbreviated puffing conditions}

Two regimens that were not used in the models (i.e., SR1 and SR-5 in Table 2) were characterized by a reduced number of puffs (i.e., 8 puffs) combined with an abbreviated total puffing duration (i.e., $<240 \mathrm{sec}$ total puffing duration). Graphical comparisons between actual and predicted lines (Figure 4-6) indicated that the models led to systematic overestimation of HPHC levels for SR-1 and SR-5 conditions, with the exception of quinoline, styrene and toluene. Quinoline exceeded predicted levels for the SR-1 regimen, where the model estimation corresponded to an interpolation between LOD and LLOQ values and the reported value was the actual LLOQ. Isoprene and toluene mean levels measured at SR-5 conditions exceeded predicted levels, but the uncertainty for these values was relatively high considering the confidence interval of the means.

The principal reason for the overestimation of constituent yields observed for both SR-1 and SR-5 regimens was attributed to the abbreviated total puffing duration. The models were constructed using longer puffing durations, exposing HeatSticks to the entire temperature increase gradient controlled by the THS device. Since the isothermal portion of the heating profile ended after $180 \mathrm{sec}$, the reduced puffing duration for SR-1 and SR-5 $(<240 \mathrm{sec})$ resulted in overall lower operating temperature conditions.

It should also be mentioned that in some cases the difference could be attributed to values being below the LLOQ for SR-1 (i.e., $m$-cresol, $p$-cresol, phenol, acrylonitrile and quinoline) and SR-5 regimens (i.e., acrylonitrile and quinoline).

\subsection{Non-linearity}

A possible reason for the "plateau and hill" effect observed for some constituents would be an evolution of vapor filtration efficiency. Assuming equal filtration of the constituents contained in the particulate phase, the level-off of aerosol constituents observed while nicotine still increased would be attributable to a dramatic augmentation of vapor filtration. However, "plateau and hill" effects were equally observed for constituents with very different physical and chemical properties (e.g., vapor pressure, polarity, chemical functionality) suggesting that the effect was more attributable to formation and release kinetic for constituents in the tobacco substrate rather than vapor filtration.

On the contrary, some components of the phenol group were characterized by a geometric increase compared to nicotine. Here again release kinetic is a possible cause of non-linearity but the evolution of selective vapor filtration efficiency due to progressive saturation of the filter cannot be excluded for these constituents. 
Table 5. HPHCs with $\mathrm{R}^{2}$ adj. $\geq 0.75$ ranked from highest to lowest values. Regression coefficients for selected models $\left(Y=A+B \times X+C \times X^{2}+D \times X^{3}\right)$, where $X$ was Nicotine MP $[\mathrm{mg} /$ HeatStick] and $Y$ was the quantity of each respective HPHC measured in aerosol.

\begin{tabular}{|c|c|c|c|c|c|c|c|c|c|c|c|}
\hline \multirow{2}{*}{ Constituent } & \multirow{2}{*}{ Unit } & \multirow{2}{*}{$\mathrm{n}$} & \multicolumn{4}{|c|}{ Parameter } & \multicolumn{4}{|c|}{ 95\% Confidence limits $( \pm)$} & \multirow{2}{*}{$R^{2}$ adj } \\
\hline & & & A & $\mathrm{B}$ & $\mathrm{C}$ & $\mathrm{D}$ & A & $\mathrm{B}$ & $\mathrm{C}$ & $\mathrm{D}$ & \\
\hline Acetamide & [ $\mathrm{\mu g} /$ HeatStick] & 25 & -5.13 & 73.1 & -193 & 188 & 2.42 & 30.1 & 108 & 116 & 0.970 \\
\hline Ammonia & [ $\mu \mathrm{g} /$ HeatStick] & 25 & -4.45 & 70.9 & & & 1.87 & 5.5 & & & 0.967 \\
\hline Phenol & [ $\mathrm{gg} /$ HeatStick] & 25 & 0.0113 & & & 91.1 & 0.4733 & & & 7.7 & 0.962 \\
\hline Catechol & {$[\mu \mathrm{g} /$ HeatStick] } & 25 & -19.9 & 287 & -696 & 525 & 7.2 & 90 & 321 & 345 & 0.960 \\
\hline Acrylamide & [ $\mu \mathrm{g} /$ HeatStick] & 25 & -0.306 & 9.11 & & & 0.303 & 0.89 & & & 0.949 \\
\hline Formaldehyde & {$[\mu \mathrm{g} /$ HeatStick] } & 25 & -0.222 & 15.5 & & & 0.58 & 1.7 & & & 0.936 \\
\hline Pyridine & {$[\mu \mathrm{g} /$ HeatStick] } & $30^{a}$ & -3.46 & 85.7 & -214 & 175 & 2.28 & 28 & 101 & 110 & 0.936 \\
\hline Hydroquinone & 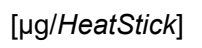 & 25 & -2.7 & 63.8 & -79.1 & & 1.46 & 10.2 & 16.3 & & 0.934 \\
\hline NO & 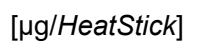 & $22^{b}$ & 0.546 & 88.5 & & -303 & 2.144 & 13.4 & & 63 & 0.933 \\
\hline Crotonaldehyde & [ug/HeatStick] & 25 & 0.372 & 12 & & -11.5 & 0.586 & 3 & & 8.8 & 0.924 \\
\hline$m$-Cresol & [ $\mu \mathrm{g} /$ HeatStick] & 25 & 0.0108 & & & 1.7 & 0.0131 & & & 0.21 & 0.919 \\
\hline $\mathrm{NO}_{\mathrm{x}}$ & [ $\mathrm{\mu g} /$ HeatStick] & $22^{b}$ & -0.686 & 101 & & -363 & 2.64 & 17 & & 78 & 0.916 \\
\hline p-Cresol & 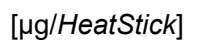 & 25 & -0.0167 & & 1.7 & & 0.0311 & & 0.22 & & 0.910 \\
\hline Ethylene oxide & [ $\mu \mathrm{g} /$ HeatStick] & 25 & 0.128 & 0.407 & & & 0.019 & 0.055 & & & 0.907 \\
\hline NAT & [ng/HeatStick] & $30^{c}$ & -13.1 & 207 & -267 & & 4.8 & 32 & 50 & & 0.906 \\
\hline o-Cresol & [ug/HeatStick] & 25 & -0.0218 & & 1.86 & & 0.0353 & & 0.25 & & 0.905 \\
\hline Quinoline & [ $\mu \mathrm{g} /$ HeatStick] & 25 & 0.000201 & & 0.213 & & 0.00428 & & 0.031 & & 0.894 \\
\hline Acrolein & [ug/HeatStick] & 25 & 0.411 & 40.7 & -31.8 & & 2.256 & 15.8 & 25.2 & & 0.892 \\
\hline NNN & [ng/HeatStick] & $30^{c}$ & -7.03 & 130 & -156 & & 3.82 & 26 & 40 & & 0.888 \\
\hline Acetone & [ $\mu \mathrm{g} /$ HeatStick] & 25 & 2.18 & 204 & -265 & & 5.87 & 41 & 65 & & 0.882 \\
\hline NNK & [ng/HeatStick] & $30^{c}$ & -2.71 & 64.9 & -80 & & 1.98 & 13.5 & 20.7 & & 0.868 \\
\hline Acrylonitrile & [jg/HeatStick] & $35^{d}$ & 0.0775 & 0.32 & & & 0.0133 & 0.043 & & & 0.868 \\
\hline Resorcinol & [ $\mu \mathrm{g} /$ HeatStick] & 25 & -0.0207 & 0.396 & -0.506 & & 0.0125 & 0.087 & 0.139 & & 0.868 \\
\hline MEK & 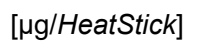 & 25 & -0.118 & 42.7 & -59.2 & & 1.216 & 8.5 & 13.6 & & 0.854 \\
\hline Butyraldehyde & [ug/HeatStick] & 25 & 8.03 & 69.7 & & -150 & 3.24 & 16.3 & & 49 & 0.816 \\
\hline Benzene & [ $\mu \mathrm{g} /$ HeatStick] & $35^{e}$ & -0.01 & 3.53 & -4.33 & & 0.1263 & 0.84 & 1.32 & & 0.797 \\
\hline Acetaldehyde & [ $\mu \mathrm{g} /$ HeatStick] & 25 & 74.2 & 740 & -1050 & & 24.8 & 174 & 280 & & 0.796 \\
\hline Propionaldehyde & [ug/HeatStick] & 25 & 2.59 & 66.9 & -95.9 & & 2.3 & 16.1 & 25.7 & & 0.780 \\
\hline
\end{tabular}

a 5 additional replicates under $\mathrm{HCl}$

${ }^{\mathrm{b}} 4$ regimens (LR-3 not applicable), 2 additional replicates at $\mathrm{HCl}$

${ }^{\mathrm{C}} 5$ additional replicates under LR-3

d 5 additional replicates under $\mathrm{HCl}$ and ISO

e 5 additional replicates under $\mathrm{HCl}$ and SR-4

Abbreviations: $\mathrm{R}^{2}$ adj. = adjusted coefficient of determination; $\mathrm{HPHC}=$ harmful and potentially harmful constituent; $\mathrm{HCl}=\mathrm{Health}$ Canada Intense; ISO = International Organization for Standardization; MEK = methyl ethyl ketone; Nicotine MP = nicotine retained in the mouthpiece of the HeatStick; $\mathrm{NO}=$ nitrogen oxide; $\mathrm{NO}_{\mathrm{x}}=$ nitrogen oxides; $\mathrm{NAT}=\mathrm{N}$-nitrosoanatabine; $\mathrm{NNN}=\mathrm{N}$-nitrosonornicotine; NNK $=4$ (methylnitrosamino)-1-(3-pyridyl)-1-butanone.

Table 6. HPHCs with forced linear regression. Regression coefficients for selected models $(Y=A+B \times X)$, where $X$ was Nicotine MP [mg/HeatStick] and $\mathrm{Y}$ was the quantity of each respective HPHC measured in aerosol.

\begin{tabular}{|c|c|c|c|c|c|c|c|}
\hline \multirow{2}{*}{ Constituent } & \multirow{2}{*}{ Unit } & \multirow{2}{*}{$\mathrm{n}$} & \multicolumn{2}{|c|}{ Parameter } & \multicolumn{2}{|c|}{ 95\% Confidence limits $( \pm)$} & \multirow{2}{*}{$\mathrm{R}^{2}$ adj. } \\
\hline & & & A & $\mathrm{B}$ & $\mathrm{A}$ & $\mathrm{B}$ & \\
\hline Acetamide & [ $\mu \mathrm{g} /$ HeatStick] & 25 & 0.0307 & 13.8 & 0.532 & 1.6 & 0.932 \\
\hline Crotonaldehyde & [ug/HeatStick] & 25 & 0.985 & 8.40 & 0.393 & 1.16 & 0.903 \\
\hline Acrolein & [ug/HeatStick] & 25 & 2.92 & 21.2 & 1.20 & 3.5 & 0.864 \\
\hline
\end{tabular}

Abbreviations: $\mathrm{R}^{2}$ adj. = adjusted coefficient of determination; HPHC = harmful and potentially harmful constituent. 
Table 7. HPHCs with $\mathbf{R}^{2}$ adj. $<0.75$ ranked from highest to lowest values. Regression coefficients for selected models $\left(Y=A+B \times X+C \times X^{2}+D \times X^{3}\right)$, where $X$ was Nicotine MP [mg/HeatStick] and $Y$ was the quantity of each respective HPHC measured in aerosol.

\begin{tabular}{|c|c|c|c|c|c|c|c|c|c|c|c|}
\hline \multirow{2}{*}{ Constituent } & \multirow{2}{*}{ Unit } & \multirow{2}{*}{$\mathrm{n}$} & \multicolumn{4}{|c|}{ Parameter } & \multicolumn{4}{|c|}{$95 \%$ Confidence limits $( \pm)$} & \multirow{2}{*}{$\mathrm{R}^{2}$ adj. } \\
\hline & & & A & $B$ & $\mathrm{C}$ & $\mathrm{D}$ & A & $\mathrm{B}$ & C & $\mathrm{D}$ & \\
\hline Toluene & [jg/HeatStick] & $30^{a}$ & -1.85 & 32.8 & -90.9 & 82.8 & 1.58 & 19.4 & 70.2 & 76.3 & 0.742 \\
\hline Styrene & {$[\mu \mathrm{g} /$ HeatStick] } & $30^{a}$ & 0.189 & 2.41 & -3.01 & & 0.11 & 0.75 & 1.18 & & 0.727 \\
\hline o-Toluidine & [ng/HeatStick] & 25 & -0.0103 & 4.85 & & & 0.6745 & 1.99 & & & 0.504 \\
\hline $\mathrm{CO}$ & [mg/HeatStick] & 25 & -0.0315 & 2.27 & & -4.45 & 0.2573 & 1.3 & & 3.87 & 0.451 \\
\hline Isoprene & [jg/HeatStick] & $30^{a}$ & 0.754 & 10.1 & -13 & & 0.767 & 5.2 & 8.2 & & 0.448 \\
\hline NAB & [ng/HeatStick] & $30^{b}$ & 2.75 & 3.19 & & & 0.6 & 1.63 & & & 0.341 \\
\hline 1,3-Butadiene & [ $\mu \mathrm{g} /$ /HeatStick] & $35^{c}$ & 0.284 & & & & 0.017 & & & & 0.000 \\
\hline Pyrene & [ng/HeatStick] & 25 & 5.55 & & & & 0.28 & & & & 0.000 \\
\hline 1-Aminonaphthalene & [ng/HeatStick] & 25 & 0.069 & & & & & & & & - \\
\hline 2-Aminonaphthalene & [ng/HeatStick] & 25 & 0.035 & & & & & & & & - \\
\hline 3-Aminobiphenyl & [ng/HeatStick] & 25 & 0.032 & & & & & & & & - \\
\hline 4-Aminobiphenyl & [ng/HeatStick] & 25 & 0.051 & & & & & & & & - \\
\hline Benzo[a]pyrene & [ng/HeatStick] & 25 & 1 & & & & & & & & - \\
\hline Dibenzo[a,h]anthracene & [ng/HeatStick] & 25 & 0.1 & & & & & & & & - \\
\hline Vinyl chloride & [ng/HeatStick] & 25 & 3.54 & & & & & & & & - \\
\hline
\end{tabular}

5 additional replicates under $\mathrm{HCl}$

5 additional replicates under LR-3

${ }^{\mathrm{c}} 5$ additional replicates under $\mathrm{HCl}$ and ISO

- Components below LLOQ under all regimens

Abbreviations: $\mathrm{R}^{2}$ adj.= adjusted coefficient of determination; $\mathrm{CO}=$ carbon monoxide; HPHC = harmful and potentially harmful constituent; $\mathrm{HCl}=$ Health Canada Intense; ISO = International Organization for Standardization; Nicotine MP = nicotine retained in the mouthpiece of the HeatStick; NAB = N-nitrosoanabasine.

\section{DISCUSSION}

A good linear relationship $\left(\mathrm{R}^{2}=0.940\right)$ between aerosol nicotine yield and nicotine content in the mouthpiece after use has been demonstrated for THS HeatSticks (FR1 blend), which is in good agreement with linear models commonly reported in similar studies conducted with cigarettes.

It should be mentioned that nicotine filtration efficiency for cigarettes has been shown to vary according to the velocity of the smoke passing through the filter (29-31). This suggested that the confidence intervals of the estimated means could be partly attributed to a variation in filtration efficiency between tested regimens. In contrast, SHEPPERD et al. (32) reported that a relatively constant filtration efficiency was observed for a wide range of smoking behaviors if part-filters (i.e., cut filters) downstream of the ventilation holes were analyzed. However, he also observed

Table 8. HPHCs below LLOQ regardless of puffing intensity.

\begin{tabular}{llr}
\hline Constituent & LLOQ & Unit \\
\hline 1-Aminonaphthalene & 0.069 & {$[\mathrm{ng} /$ HeatStick] } \\
2-Aminonaphthalene & 0.035 & {$[\mathrm{ng} /$ HeatStick] } \\
3-Aminobiphenyl & 0.032 & {$[\mathrm{ng} /$ HeatStick] } \\
4-Aminobiphenyl & 0.051 & {$[\mathrm{ng} /$ HeatStick] } \\
Benzo[a]pyrene & 1.0 & {$[\mathrm{ng} /$ HeatStick] } \\
Dibenzo[a,h]anthracene & 0.10 & {$[\mathrm{ng} /$ HeatStick] } \\
Vinyl chloride & 3.54 & {$[\mathrm{ng} /$ HeatStick] } \\
\hline
\end{tabular}

Abbreviations: HPHC = harmful and potentially harmful constituent; LLOQ = lower limit of quantitation. deviations that were probably due to a dominant condensation effect on nicotine filtration with very low filtration efficiency filters, or dual filters with low efficiency mouth sections. Considering that a THS HeatStick has no ventilation holes and has a filter section made of polylactic acid (PLA) coupled with a low efficiency mouthpiece, some influence of flow rate upon filtration efficiency could be reasonably expected, thereby affecting linearity for the Nicotine-to-Nicotine MP relationship. Nevertheless, a good fit was observed using a linear model for THS HeatSticks. Tests conducted with both unconfined and confined users indicated that the range of machine-smoking regimens selected adequately covered the range of human-smoking conditions observed. Less than $2 \%$ of mouthpiece samples produced by human-smoking had nicotine concentrations outside the range covered by the machine-smoked model (i.e., Nicotine MP 0.12 to $0.49 \mathrm{mg} /$ HeatStick). This range corresponded to aerosol nicotine yields of between 0.49 and $2.19 \mathrm{mg}$ nicotine/HeatStick.

There was a significant difference in Nicotine MP levels observed between the unconfined and the confined population of THS users, which was attributed to experimental conditions. These results suggest that the method should be sensitive enough to discriminate between situations where subjects use THS HeatSticks under different experimental conditions.

In a large majority of cases (i.e., 28 out of 43 measured HPHCs), regression analysis resulted in models with good coefficients of determination $\left(\mathrm{R}^{2}\right.$ adj. $\left.>0.750\right)$. Linear models were found appropriate for nicotine, ammonia, acrolein, acrylamide acrylonitrile, ethylene oxide, crotonaldehyde, formaldehyde and $o$-toluidine. However, non- 
Table 9. HPHCs with models characterized by a constant value regardless of puffing intensity.

\begin{tabular}{lcccc}
\hline Constituent & Intercept $\pm \mathrm{CL}$ & LLOQ & Unit \\
\hline 1,3-Butadiene $^{\mathrm{a}}$ & $0.284 \pm 0.017$ & 0.24 & {$[\mu \mathrm{\mu g} /$ HeatStick $]$} \\
Pyrene $^{\mathrm{b}}$ & $5.55 \pm 0.28$ & 5.0 & {$[\mathrm{ng} /$ HeatStick } \\
\hline
\end{tabular}

a 9 out of 35 values estimated by LLOQ

b 12 out of 25 values estimated by LLOQ

Abbreviations: $\mathrm{HPHC}=$ harmful and potentially harmful constituent; $\quad C L=$ confidence limit; $L L O Q=$ lower limit of quantitation.

linear models were characteristic for most of the aerosol constituents considered.

Phenol, cresols and quinoline were characterized with either quadratic or cubic functions of Nicotine MP, indicative of the complex kinetics for formation and transfer of these aerosol constituents and justifying the application of non-linear models in these cases. Similar effects were observed for constituents such as NNK and $\mathrm{NNN}$, but limited to transfer kinetic effects since they were already present in the tobacco plug and would not be formed in-situ. Complex models were required to fit the depletion of these constituents, characterized by a "plateau and hill" curve shape with the increase of Nicotine MP. In these cases, non-linear and polynomial functions in the form $\mathrm{y}=\mathrm{a}+\mathrm{bx}+\mathrm{cx}^{2}$ with $\mathrm{c}<0$ were selected.

Determining the reason for these non-linear relationships between aerosol constituents and Nicotine MP was not in the scope of this study. Nevertheless, this could be partly attributed to formation and transfer kinetics, which are different for each of the constituents. The distribution of temperatures in the heated tobacco plug, combined with the changes in tobacco substrate composition during HeatStick use, would be also a reasonable explanation for non-linearity. Hence, a log transformation of aerosol constituent levels could be suggested for the non-linear models. Nevertheless, in the absence of a mechanistic demonstration, a general conclusion is that models based on polynomial functions are meaningful for prediction purposes.

Using abbreviated machine-smoking conditions, substantial differences were observed for some constituents between actual and predicted values, showing a limitation in the application of the models if smokers deviate from the conditions used during model development. As a result, this approach presents serious limitation for the prediction of MLE. Nevertheless, the fact that puffing durations used to generate the models represent the maximum possible usage conditions, and that any abbreviated use of THS leads to an over-estimate of aerosol constituent deliveries, the approach can be reasonably applied to estimate the upper limit of users' mouth level exposure.

\section{CONCLUSIONS}

This study has demonstrated that nicotine measured in the aerosol of machine-smoked THS HeatSticks was linearly correlated with the nicotine level retained in the mouth- piece (i.e., Nicotine MP). This condition was required to justify the subsequent development of models for other aerosol constituents.

The practical range of Nicotine MP levels from machinesmoking used for the development of models was demonstrated to be a good match for Nicotine MP measured in used HeatSticks collected from THS users. The smokingmachine regimens used adequately covered the range of human-smoking conditions.

In addition to nicotine, the developed regression models showed a good coefficient of determination $\left(R^{2} \mathrm{adj}\right.$.) for 28 out of 43 HPHCs. On the contrary, the methodology was found unsuitable for 12 aerosol constituents that showed $\mathrm{R}^{2}$ adj. values below 0.51 , due either to the absence of discrimination between regimens or because measured levels were borderline or below the LLOQ for the analytical methods.

One important observation highlighted that models would overestimate levels of aerosol constituents if THS was used with an abbreviated total puffing duration. In other words, a single level of Nicotine MP could derive from different puffing conditions, which would result in different levels of delivery for other aerosol constituents. This was identified as a serious limitation for estimating MLE with THS HeatStick use. Nevertheless, the approach can be reasonably applied to estimate the upper limits of users' mouth level exposure to aerosol constituents since the total puffing duration used in machine-smoking experiments represented maximum possible usage conditions. The incorporation of total puffing duration as an additional parameter in the model to improve the prediction for MLE of THS users could be considered.

From a modeling perspective, the kinetics of formation and transfer for aerosol constituents was presumed to be the underlying reason for non-linearity. Further work to explore the use of specific transformations (e.g., log transformation) to improve models based upon this supposition is therefore warranted.

To improve the prediction of aerosol nicotine yield, since the HeatStick is heated and not burned, the determination of residual nicotine in the used stick could be considered as an alternative, or complementary to the analysis of nicotine in mouthpiece filters.

Independent smoking topography studies were performed in the frame of a global clinical program to assess THS. HST data were not available when this study was started, however a retrospective comparison was possible. The machine-smoking regimens that were used for the determination of the models and that were based on maximum possible usage conditions were found in line with HST.

\section{REFERENCES}

1. Ashton, H. and D.W. Watson: Puffing Frequency and Nicotine Intake in Cigarette Smokers; Brit. Med. J. 3 (1970) 679-681.

2. Forbes, W.F., J.C. Robinson, J.A. Hanley, and H.N. Colburn: Studies on the Nicotine Exposure of Individual Smokers. I. Changes in Mouth Level Exposure to Nicotine on Switching to Lower Nicotine Cigarettes; Int. J. Addict. 11 (1976) 933-950. 
3. Schulz, W. and F. Seehofer: Smoking Behaviour in Germany - The Analysis of Cigarette Butts (KIPA); in: Smoking Behaviour, edited by R.E. Thornton, Churchill-Livingstone, Edinburgh, United Kingdom, 1978, pp. 259-276.

4. Hyodo, T., K. Minagawa, T. Inoue, J. Fujimoto, N. Minami, R. Bito, and A. Mikita: Estimation of Mouth Level Exposure to Smoke Constituents of Cigarettes with Different "Tar" Levels Using Filter Analysis; Regul. Toxicol. Pharmacol. 67 (2013) 486-498. DOI: 10.1016/j.yrtph.2013.09.009

5. Ding YS, J. Ward, D. Hammond, and C.H. Watson: Mouth-Level Intake of Benzo[a]pyrene from Reduced Nicotine Cigarettes; Int. J. Environ. Res. Public. Health 11 (2014) 11898-11914. DOI: 10.3390/ijerph111111 898

6. Pauly, J.L., R.J. O’Connor, G.M. Paszkiewicz, K.M. Cummings, M.V. Djordjevic, and P.G. Shields: Cigarette Filter-Based Assays as Proxies for Toxicant Exposure and Smoking Behavior - A Literature Review; Cancer. Epidemiol. Biomarkers Prev. 18 (2009) 3321-3333. DOI: 10.1158/1055-9965.EPI-090925

7. Clayton, P.M., K. Prasad, and A. Sisodiya:The Development and Application of a Method for the Estimation of Mouth Level Exposure (MLE) to Four Tobacco Specific Nitrosamines; CORESTA Congress, Edinburgh, 2010, SS 10. Available at: https://www.coresta.org/abstracts/development-andapplication-method-estimation-mouth-level-exposuremle-four-tobacco (accessed November 2016)

8. Moldoveanu, S., W. Coleman III, and J. Wilkins: Determination of Carbonyl Compounds in Exhaled Cigarette Smoke; Beitr. Tabakforsch. Int. 22 (2007) 346-357. DOI: $10.2478 / \mathrm{cttr}-2013-0841$

9. Moldoveanu, S., W. Coleman III, and J. Wilkins: Determination of Hydroxybenzenes in Exhaled Cigarette Smoke; Beitr. Tabakforsch. Int. 23 (2008) 97-105. DOI: $10.2478 /$ cttr-2013-0852

10. Moldoveanu, S., W. Coleman III, and J. Wilkins: Determination of Polycyclic Aromatic Hydrocarbons in Exhaled Cigarette Smoke; Beitr. Tabakforsch. Int. 23 (2008) 85-97. DOI: 10.2478/cttr-2013-0851

11. Moldoveanu, S., W. Coleman III, and J. Wilkins: Determination of Benzene and Toluene in Exhaled Cigarette Smoke; Beitr. Tabakforsch. Int. 23 (2008) 107-114. DOI: $10.2478 /$ cttr-2013-0853

12. Urban, H.J., A.R. Tricker, D.E. Leyden, N. Forte, V. Zenzen, A. Feuersenger, M. Assink, G. Kallischnigg, and M.K. Schorp: Reduced Exposure Evaluation of an Electrically Heated Cigarette Smoking System - Part 8: Nicotine Bridging - Estimating Smoke Constituent Exposure by their Relationships to Both Nicotine Levels in Mainstream Cigarette Smoke and in Smokers; Regul. Toxicol. Pharmacol. 64 Suppl. (2012) S85-S97. DOI:10.1016/j.yrtph.2012.08.005

13. Zenzen, V., J. Diekmann, B. Gerstenberg, S. Weber, S. Wittke, and M.K. Schorp: Reduced Exposure Evaluation of an Electrically Heated Cigarette Smoking System - Part 2: Smoke Chemistry and In Vitro Toxicological Evaluation Using Smoking Regimens Reflecting Human Puffing Behavior; Regul. Toxicol.
Pharmacol. 64 Suppl. 2 (2012) S11-S34. DOI: 10.1016/j.yrtph.2012.08.004

14. De La Bourdonnaye, G., T. Bachmann, C. Haziza, P. Picavet, G. Baker, D. Skiada, K. Jarus-Dziedzic, and F. Lüdicke: Investigation on Puffing Topography Parameters and Product Evaluation Recorded During Five Days of Use of the Tobacco Heating System 2.2. A Comparison With Continued Combustible Cigarette Use. Available at: https://www.pmiscience.com/library/ investigation-puffing-topography-parameters-andproduct-evaluation-recorded-during-five-days (accessed November, 2016)

15. International Organization of Standardization (ISO): ISO 3402:1999 Tobacco and Tobacco Products Atmosphere for Conditioning and Testing; ISO, Geneva, Switzerland, 1999. Available at: http://www.iso.org/iso/home/store/catalogue_tc/catalo gue_detail.htm?csnumber $=28324$ (accessed November, 2016)

16. International Organization of Standardization (ISO): ISO 4387: 2000 Cigarettes - Determination of Total and Nicotine Free Dry Particulate Matter Using a Routine Analytical Smoking Machine; ISO, Geneva, Switzerland, 2000. Available at: http://www.iso.org/iso/ iso_catalogue/catalogue_tc/catalogue_detail.htm?csnu mber $=28323$ (accessed November, 2016)

17. Health Canada: Official Method T-115-Determination of "Tar", Nicotine and Carbon Monoxide in Mainstream Tobacco; 1999.

18. International Organization of Standardization (ISO): ISO 8454:2007 Cigarettes - Determination of Carbon Monoxide in the Vapour Phase of Cigarette Smoke NDIR Method; ISO, Geneva, Switzerland, 2007. Available at: http://www.iso.org/iso/home/store/ catalogue_tc/catalogue_detail.htm?csnumber $=41168$ (accessed $\bar{N}$ ovember, 2016 )

19. International Organization of Standardization (ISO): ISO 10315:2013 Cigarettes - Determination of Nicotine in Smoke Condensates - Gas-Chromatographic Method; ISO, Geneva, Switzerland, 2013. Available at: http://www.iso.org/iso/home/store/catalogue tc/catalo gue detail.htm?csnumber $=56744$ (accessed November, 2016)

20. Cooperation Centre for Scientific Research Relative to Tobacco (CORESTA): CORESTA Recommended Method CRM No 70 - Determination of Selected Volatile Organic Compounds in Mainstream Cigarette Smoke by GC-MS; CORESTA, Paris, France, 2014. Available at https://www.coresta.org/sites/default/ files/technical_documents/main/CRM 70-update \%28July14\%29.pdf (accessed November, 2016)

21. Health Canada: Official Method T-112-Determination of Pyridine, Quinoline and Styrene in Mainstream Tobacco Smoke; 1999.

22. Cooperation Centre for Scientific Research Relative to Tobacco (CORESTA): CORESTA Recommended Method CRM No 74 - Determination of Selected Carbonyls in Mainstream Cigarette Smoke by HPLC; CORESTA, Paris, France, 2014. Available at https:// www.coresta.org/sites/default/files/technical_documents/ main/CRM_74-update\%28July14\%29.pdf (accessed November, 2016) 
23. Health Canada: Official Method T-102-Determination of 1- and 2-Aminonapthalene and 3- and 4-Aminobiphenyl in Mainstream Tobacco Smoke, 1999.

24. Health Canada: Official Method T-110 - Determination of Oxides of Nitrogen in Mainstream Tobacco Smoke, 1999.

25. Cooperation Centre for Scientific Research Relative to Tobacco (CORESTA): CORESTA Recommended Method CRM 79 - Determination of Ammonia in Tobacco by Ion Chromatographic Analysis; CORESTA, Paris, France, 2015. Available at: https://www.coresta.org/sites/default/files/technical_ documents/main/CRM_79.pdf (accessed November 2016)

26. Cooperation Centre for Scientific Research Relative to Tobacco (CORESTA): CORESTA Recommended Method CRM No 75 - Determination of Tobacco Specific Nitrosamines in Mainstream Cigarette Smoke by LC-MS/MS; CORESTA, Paris, France, 2014. Available at: https://www.coresta.org/sites/default/files /technical_documents/main/CRM_75-updateJuly14.pdf (accessed November, 2016)

27. International Organization of Standardization (ISO): ISO 22634:2008 Determination of Benzo[a]pyrene in Cigarette Mainstream Smoke - Method Using Gas Chromatography/Mass Spectrometry; ISO, Geneva, Switzerland, 2000. Available at: http://www.iso.org/ iso/home/store/catalogue_tc/catalogue_detail.htm?csn umber $=41040$ (accessed November, 2016)

28. Cooperation Centre for Scientific Research Relative to Tobacco (CORESTA): CORESTA Recommended Method CRM No 9 - Determination of Nicotine in Cigarette Filters by Gas Chromatographic Analysis;
CORESTA, Paris, France, 2009. Available at https://www.coresta.org/sites/default/files/technical d ocuments/main/CRM_09-update2.pdf (accessed November, 2016)

29. Overton, J.R.: Filtration of Cigarette Smoke: Relative Contributions of Inertial Impaction, Diffusional Deposition, and Direct Impaction; Beitr. Tabakforsch. 7 (1973) 117-120. DOI: 10.2478/cttr-2013-0319

30. Dwyer, R.W. and S.G. Abel: The Efficiencies of Cellulose Acetate Filters; Beitr. Tabakforsch. Int. 13 (1986) 243-253. DOI: 10.2478/cttr-2013-0574

31. Norman, V., A.M. Ihrig, R.A. Shoffner, and M.S. Ireland: The Effect of Tip Dilution on the Filtration Efficiency of Upstream and Downstream Segments of Cigarette Filters; Beitr. Tabforsch. Int. 12 (1984) 178-185. DOI: $10.2478 /$ cttr-2013-0539

32. Shepperd, C.J., F.K. St. Charles, M. Lien, and M. Dixon: Validation of Methods for Determining Consumer Smoked Cigarette Yields from Cigarette Filter Analysis; Beitr. Tabforsch. Int. 22 (2006) 176-184. DOI: $10.2478 /$ cttr-2013-0826

Corresponding author:

Laurent Poget

Philip Morris International

Quai Jeanrenaud 5

2000 Neuchâtel, Switzerland

E-mail:laurent.poget@pmi.com 


\section{APPENDIX}

Table 10. Descriptive statistics of HST parameters per cigarette - FAS. Subjects used their preferred brand of cigarette at baseline, and then switched to THS for 5 days. This was an ad-libitum product use study. Puff characteristics (e.g., puff volume, duration or interval) was assessed using a HST SODIM ${ }^{\circledR}$ device, model SPA/M (SODIM ${ }^{\circledR}$ Instrumentation, Fleury-les-Aubrais, France). Parameters were recorded at baseline, Day 1 and Day 4 for all subjects.

\begin{tabular}{|c|c|c|c|c|c|c|}
\hline $\begin{array}{l}\text { Total puff volume }(\mathrm{mL}) \\
\text { (average over visit) }\end{array}$ & Day 1 & $\begin{array}{l}\mathrm{n} \\
\text { Mean (SD) } \\
95 \% \mathrm{Cl} \\
\text { Median } \\
\text { Q25, Q75 } \\
\text { Min, max }\end{array}$ & $\begin{array}{l}79 \\
792.83(310.144) \\
725.37,860.28 \\
784.72 \\
585.02,984.67 \\
226.8,1417.5\end{array}$ & Day 4 & $\begin{array}{l}\mathrm{n} \\
\text { Mean (SD) } \\
95 \% \mathrm{Cl} \\
\text { Median } \\
\text { Q25, Q75 } \\
\text { Min, max }\end{array}$ & $\begin{array}{l}78 \\
810.55(257.816) \\
752.42,868.68 \\
834.52 \\
654.66,970.78 \\
160.3,1566.9\end{array}$ \\
\hline $\begin{array}{l}\text { Average puff volume (mL) } \\
\text { (average over visit) }\end{array}$ & Day 1 & $\begin{array}{l}\mathrm{n} \\
\text { Mean (SD) } \\
95 \% \mathrm{Cl} \\
\text { Median } \\
\text { Q25, Q75 } \\
\text { Min, max }\end{array}$ & $\begin{array}{l}79 \\
50.62(19.501) \\
46.25,54.99 \\
53.95 \\
35.60,63.32 \\
9.9,105.7\end{array}$ & Day 4 & $\begin{array}{l}\mathrm{n} \\
\text { Mean (SD) } \\
95 \% \mathrm{Cl} \\
\text { Median } \\
\text { Q25, Q75 } \\
\text { Min, max }\end{array}$ & $\begin{array}{l}78 \\
52.91(18.467) \\
48.74,57.08 \\
52.82 \\
43.08,63.05 \\
9.9,133.3\end{array}$ \\
\hline $\begin{array}{l}\text { Average puff duration (sec) } \\
\text { (average over visit) }\end{array}$ & Day 1 & $\begin{array}{l}\mathrm{n} \\
\text { Mean (SD) } \\
95 \% \mathrm{Cl} \\
\text { Median } \\
\text { Q25, Q75 } \\
\text { Min, max }\end{array}$ & $\begin{array}{l}79 \\
2.02(0.705) \\
1.85,2.18 \\
2.00 \\
1.46,2.46 \\
0.6,3.8\end{array}$ & Day 4 & $\begin{array}{l}\mathrm{n} \\
\text { Mean (SD) } \\
95 \% \mathrm{Cl} \\
\text { Median } \\
\text { Q25, Q75 } \\
\text { Min, max }\end{array}$ & $\begin{array}{l}78 \\
2.12(0.819) \\
1.93,2.31 \\
2.03 \\
1.48,2.65 \\
0.6,4.7\end{array}$ \\
\hline $\begin{array}{l}\text { Average flow (mL/sec) } \\
\text { (average over visit) }\end{array}$ & Day 1 & $\begin{array}{l}\mathrm{n} \\
\text { Mean (SD) } \\
95 \% \mathrm{Cl} \\
\text { Median } \\
\text { Q25, Q75 } \\
\text { Min, max }\end{array}$ & $\begin{array}{l}79 \\
26.30(6.914) \\
24.75,27.86 \\
25.40 \\
22.51,31.10 \\
9.5,41.9\end{array}$ & Day 4 & $\begin{array}{l}\mathrm{n} \\
\text { Mean (SD) } \\
95 \% \mathrm{Cl} \\
\text { Median } \\
\text { Q25, Q75 } \\
\text { Min, max }\end{array}$ & $\begin{array}{l}78 \\
27.15(7.237) \\
25.51,28.79 \\
26.32 \\
21.94,32.44 \\
15.2,45.9\end{array}$ \\
\hline $\begin{array}{l}\text { Total smoking duration (sec) } \\
\text { (average over visit) }\end{array}$ & Day 1 & $\begin{array}{l}\mathrm{n} \\
\text { Mean (SD) } \\
95 \% \mathrm{Cl} \\
\text { Median } \\
\text { Q25, Q75 } \\
\text { Min, max }\end{array}$ & $\begin{array}{l}79 \\
2019.70(47.256) \\
199.11,220.29 \\
211.64 \\
171.56,235.96 \\
109.4,314.4\end{array}$ & Day 4 & $\begin{array}{l}\mathrm{n} \\
\text { Mean (SD) } \\
95 \% \mathrm{Cl} \\
\text { Median } \\
\text { Q25, Q75 } \\
\text { Min, max }\end{array}$ & $\begin{array}{l}78 \\
200.75(52.523) \\
188.91,212.60 \\
194.28 \\
158.83,246.36 \\
106.3,323.4\end{array}$ \\
\hline $\begin{array}{l}\text { Total number of puffs } \\
\text { (average over visit) }\end{array}$ & Day 1 & $\begin{array}{l}\mathrm{n} \\
\text { Mean (SD) } \\
95 \% \mathrm{Cl} \\
\text { Median } \\
\text { Q25, Q75 } \\
\text { Min, max }\end{array}$ & $\begin{array}{l}79 \\
16.20(3.521) \\
15.41,16.99 \\
15.42 \\
13.90,17.90 \\
10.7,28.9\end{array}$ & Day 4 & $\begin{array}{l}\mathrm{n} \\
\text { Mean (SD) } \\
95 \% \mathrm{Cl} \\
\text { Median } \\
\text { Q25, Q75 } \\
\text { Min, max }\end{array}$ & $\begin{array}{l}78 \\
15.78(2.796) \\
15.14,16.41 \\
15.15 \\
13.94,17.00 \\
9.1,23.4\end{array}$ \\
\hline
\end{tabular}

Abbreviations: HST = human smoking topography; FAS = full analysis set; SD = standard deviation; $\mathrm{Cl}=$ confidence interval; $\mathrm{Q} 25=$ $1^{\text {st }}$ quartile; $\mathrm{Q} 75=3^{\text {rd }}$ quartile; HST = human smoking topography;

Note: average over visit = average over 24 hours. 
Table 11. HPHCs yields measured using ISO, HCl, SR-4, and SR-6 regimens.

\begin{tabular}{|c|c|c|c|c|c|c|c|c|c|c|c|c|c|c|}
\hline \multirow{2}{*}{ Group } & \multirow{2}{*}{ Constituent } & \multirow{2}{*}{ Unit } & \multicolumn{3}{|c|}{ ISO } & \multicolumn{3}{|c|}{$\mathrm{HCl}$} & \multicolumn{3}{|c|}{ SR-4 } & \multicolumn{3}{|c|}{ SR-6 } \\
\hline & & & Mean & SD & $\mathrm{n}$ & Mean & SD & $\mathrm{n}$ & Mean & SD & $\mathrm{n}$ & Mean & SD & $\mathrm{n}$ \\
\hline Acetamide & Acetamide & [ $\mu \mathrm{g} /$ HeatStick] & 1.32 & 0.07 & 5 & 4.18 & 0.07 & 5 & 4.62 & 0.34 & 5 & 5.21 & 0.21 & 5 \\
\hline Acrylamide & Acrylamide & [ug/HeatStick] & 0.69 & 0.06 & 5 & 2.33 & 0.07 & 5 & 2.64 & 0.27 & 5 & 2.96 & 0.15 & 5 \\
\hline \multirow{5}{*}{$\begin{array}{l}\text { Aromatic } \\
\text { amines }\end{array}$} & 1-Aminonaphthalene & [ng/HeatStick] & $0.069^{a}$ & - & 5 & $0.069^{a}$ & 0 & 4 & $0.069^{a}$ & - & 5 & $0.069^{a}$ & - & 4 \\
\hline & 2-Aminonaphthalene & [ng/HeatStick] & $0.035^{\mathrm{a}}$ & - & 5 & $0.035^{a}$ & 0 & 5 & $0.035^{a}$ & - & 5 & $0.035^{a}$ & - & 4 \\
\hline & 3-Aminobiphenyl & [ng/HeatStick] & $0.032^{a}$ & - & 5 & $0.032^{a}$ & 0 & 5 & $0.032^{a}$ & - & 5 & $0.032^{a}$ & - & 4 \\
\hline & 4-Aminobiphenyl & [ng/HeatStick] & $0.051^{\mathrm{a}}$ & - & 5 & $0.051^{a}$ & 0 & 5 & $0.051^{a}$ & - & 5 & $0.051^{a}$ & - & 5 \\
\hline & o-Toluidine & [ng/HeatStick] & 0.53 & 0.08 & 5 & 1.2 & 0.09 & 5 & 1.27 & 0.16 & 5 & 2.58 & 0.97 & 5 \\
\hline \multirow[t]{8}{*}{ Carbonyls } & Acetaldehyde & [ug/HeatStick] & 149 & 8 & 5 & 196 & 10 & 5 & 205 & 8 & 5 & 203 & 10 & 5 \\
\hline & Acetone & [ug/HeatStick] & 23.2 & 1.7 & 5 & 37.9 & 1.3 & 5 & 40.7 & 1.9 & 5 & 40.6 & 1.9 & 5 \\
\hline & Acrolein & [ $\mathrm{gg} /$ HeatStick] & 4.9 & 0.6 & 5 & 8.8 & 0.6 & 5 & 10.6 & 0.6 & 5 & 10.7 & 0.5 & 5 \\
\hline & Butyraldehyde & [ug/HeatStick] & 16.7 & 0.6 & 5 & 22 & 1.1 & 5 & 26.2 & 0.8 & 5 & 26.7 & 1.2 & 5 \\
\hline & Crotonaldehyde & [ug/HeatStick] & 1.88 & 0.14 & 5 & 3.04 & 0.16 & 5 & 4.06 & 0.25 & 5 & 4.29 & 0.17 & 5 \\
\hline & Formaldehyde & [ug/HeatStick] & 1.85 & 0.19 & 5 & 3.77 & 0.39 & 5 & 4.62 & 0.36 & 5 & 5.34 & 0.43 & 5 \\
\hline & MEK & [ug/HeatStick] & 4.18 & 0.25 & 5 & 7.28 & 0.41 & 5 & 7.39 & 0.4 & 5 & 7.33 & 0.44 & 5 \\
\hline & Propionaldehyde & [ng/HeatStick] & 9.4 & 0.5 & 5 & 13.5 & 1.4 & 5 & 14.4 & 0.5 & 5 & 13.9 & 0.5 & 5 \\
\hline \multirow{5}{*}{$\begin{array}{l}\text { Ethylene oxide } \\
\text { Inorganics }\end{array}$} & Ethylene oxide & [ug/HeatStick] & 0.174 & 0.007 & 5 & 0.242 & 0.019 & 5 & 0.248 & 0.01 & 5 & 0.294 & 0.022 & 5 \\
\hline & Ammonia & [ug/HeatStick] & 4.1 & 0.2 & 5 & 15 & 0.4 & 5 & 17.7 & 1.6 & 5 & 21.8 & 2.9 & 5 \\
\hline & NO & [ug/HeatStick] & 11 & 0.3 & 5 & 18 & 1.2 & 7 & 19.4 & 0.7 & 5 & 17.3 & 0.4 & 5 \\
\hline & $\mathrm{NO}_{\mathrm{x}}$ & [ng/HeatStick] & 11.2 & 0.3 & 5 & 19 & 1.6 & 7 & 20.3 & 0.9 & 5 & 17.6 & 0.4 & 5 \\
\hline & $\mathrm{CO}$ & [mg/HeatStick] & 0.238 & 0.016 & 5 & 0.532 & 0.193 & 5 & 0.436 & 0.054 & 5 & 0.66 & 0.134 & 5 \\
\hline \multirow[t]{3}{*}{ PAHs } & Benzo[a]pyrene & [ng/HeatStick] & $1^{a}$ & - & 5 & $1^{\mathrm{a}}$ & - & 5 & $1^{a}$ & - & 5 & $1^{a}$ & - & 5 \\
\hline & Dibenzo[a,h]anthracene & [ng/HeatStick] & $0.1^{\mathrm{a}}$ & - & 5 & $0.1^{\mathrm{a}}$ & - & 5 & $0.1^{\mathrm{a}}$ & - & 5 & $0.1^{\mathrm{a}}$ & - & 5 \\
\hline & Pyrene & [ng/HeatStick] & $5^{a}$ & - & 5 & $5^{a}$ & - & 5 & 6.5 & 0.2 & 5 & 6.15 & 0.41 & 5 \\
\hline \multirow[t]{7}{*}{ Phenols } & Catechol & [ug/HeatStick] & 5.9 & 0.3 & 5 & 16.8 & 0.6 & 5 & 17.9 & 1.5 & 5 & 17.4 & 0.6 & 5 \\
\hline & Hydroquinone & [ng/HeatStick] & 3.9 & 0.3 & 5 & 8.8 & 0.3 & 5 & 9.5 & 0.8 & 5 & 10 & 0.5 & 5 \\
\hline & $m$-Cresol & [ug/HeatStick] & $0.01^{a}$ & - & 5 & 0.046 & 0.004 & 5 & 0.058 & 0.013 & 5 & 0.115 & 0.008 & 5 \\
\hline & o-Cresol & [ug/HeatStick] & 0.021 & 0.003 & 5 & 0.108 & 0.01 & 5 & 0.131 & 0.028 & 5 & 0.262 & 0.012 & 5 \\
\hline & $p$-Cresol & [ug/HeatStick] & 0.02 & 0.001 & 5 & 0.1 & 0.01 & 5 & 0.122 & 0.028 & 5 & 0.25 & 0.016 & 5 \\
\hline & Phenol & [ug/HeatStick] & $0.1^{\mathrm{a}}$ & - & 5 & 1.9 & 0.2 & 5 & 2.5 & 0.6 & 5 & 5.5 & 0.3 & 5 \\
\hline & Resorcinol & [ug/HeatStick] & 0.021 & 0.002 & 5 & 0.047 & 0.004 & 5 & 0.055 & 0.007 & 5 & 0.056 & 0.005 & 5 \\
\hline \multirow[t]{4}{*}{ TSNAs } & NAB & [ng/HeatStick] & $3.15^{a}$ & - & 5 & 3.46 & 0.24 & 5 & 3.93 & 0.09 & 5 & 3.92 & 0.21 & 5 \\
\hline & NAT & [ng/HeatStick] & 8.5 & 0.7 & 5 & 22.4 & 1.8 & 5 & 26.3 & 1.1 & 5 & 26.8 & 1.6 & 5 \\
\hline & NNK & [ng/HeatStick] & 4.1 & 0.2 & 5 & 8.7 & 0.4 & 5 & 10.1 & 0.7 & 5 & 10.2 & 1 & 5 \\
\hline & NNN & [ng/HeatStick] & 6.5 & 0.5 & 5 & 16.1 & 0.7 & 5 & 19 & 1.2 & 5 & 19 & 1.3 & 5 \\
\hline Vinyl chloride & Vinyl chloride & [ng/HeatStick] & $3.54^{\mathrm{a}}$ & - & 5 & $3.54^{\mathrm{a}}$ & - & 5 & $3.54^{\mathrm{a}}$ & - & 5 & $3.54^{\mathrm{a}}$ & - & 5 \\
\hline \multirow{8}{*}{$\begin{array}{l}\text { Volatiles and } \\
\text { semi-volatiles }\end{array}$} & 1,3-Butadiene & [ug/HeatStick] & 0.25 & 0.021 & 10 & 0.295 & 0.052 & 10 & 0.357 & 0.057 & 5 & 0.279 & 0.016 & 5 \\
\hline & Acrylonitrile & [ $\mu \mathrm{g} /$ HeatStick] & 0.114 & 0.006 & 10 & 0.163 & 0.015 & 10 & 0.178 & 0.028 & 5 & 0.209 & 0.011 & 5 \\
\hline & Benzene & [ug/HeatStick] & 0.362 & 0.04 & 5 & 0.597 & 0.048 & 10 & 0.708 & 0.058 & 10 & 0.665 & 0.044 & 5 \\
\hline & Isoprene & [ug/HeatStick] & 1.78 & 0.35 & 5 & 2.56 & 0.34 & 10 & 2.51 & 0.38 & 5 & 2.74 & 0.25 & 5 \\
\hline & Pyridine & [ug/HeatStick] & 4.21 & 0.37 & 5 & 7.36 & 0.31 & 10 & & 0.41 & 5 & 7.67 & 0.31 & 5 \\
\hline & Quinoline & [ng/HeatStick] & $0.003^{b}$ & - & 5 & 0.019 & 0.003 & 5 & $0.012^{a}$ & - & 5 & 0.036 & 0.004 & 5 \\
\hline & Styrene & [ug/HeatStick] & 0.439 & 0.042 & 5 & 0.619 & 0.051 & 10 & 0.619 & 0.043 & 5 & 0.686 & 0.048 & 5 \\
\hline & Toluene & [ug/HeatStick] & 1 & 0.3 & 5 & 2 & 0.2 & 10 & 2 & 0.3 & 5 & 2.1 & 0.1 & 5 \\
\hline
\end{tabular}

\footnotetext{
${ }^{a}$ Lower Limit of Quantification

${ }^{b}$ Limit of Detection

- Standard deviation not mentioned below the lower limit of determination
}

Abbreviations: $\mathrm{CO}=$ carbon monoxide $; \mathrm{HCl}=$ Health Canada Intense; ISO = International Organization for Standardization; $\mathrm{HPHC}=$ harmful and potentially harmful constituent; $\mathrm{MEK}=$ methyl ethyl ketone; $\mathrm{NO}=$ nitrogen oxide; $\mathrm{NO}_{\mathrm{x}}=$ nitrogen oxides; $\mathrm{NAB}=\mathrm{N}$-nitrosoanabasine, NAT = N-nitrosoanatabine, NNK = 4-(methylnitrosamino)-1-(3-pyridyl)-1-butanone; NNN = N-nitrosonornicotine; $\mathrm{SD}=$ standard deviation; $\mathrm{PAHs}=$ polyaromatic hydrocarbons; TSNAs = tobacco-specific nitrosamines; SR-4 and SR-6 are arbitrary names. 
Table 12. HPHCs yields measured using SR-1, SR-5, and LR-3 regimens.

\begin{tabular}{|c|c|c|c|c|c|c|c|c|c|c|c|}
\hline \multirow{2}{*}{ Group } & \multirow{2}{*}{ Constituent } & \multirow{2}{*}{ Unit } & \multicolumn{3}{|c|}{ SR-1 } & \multicolumn{3}{|c|}{ SR-5 } & \multicolumn{3}{|c|}{ LR-3 } \\
\hline & & & Mean & SD & $\mathrm{n}$ & Mean & SD & $\mathrm{n}$ & Mean & SD & $\mathrm{n}$ \\
\hline Acetamide & Acetamide & [ $\mu \mathrm{g} /$ HeatStick] & 1.63 & 0.25 & 5 & 2.91 & 0.14 & 5 & 6.62 & 0.57 & 5 \\
\hline Acrylamide & Acrylamide & [ug/HeatStick] & 0.92 & 0.16 & 5 & 2.04 & 0.13 & 5 & 4.23 & 0.34 & 5 \\
\hline \multirow{5}{*}{$\begin{array}{l}\text { Aromatic } \\
\text { amines }\end{array}$} & 1-Aminonaphthalene & [ng/HeatStick] & $0.069^{a}$ & - & 5 & $0.069^{a}$ & - & 5 & $0.069^{a}$ & - & 5 \\
\hline & 2-Aminonaphthalene & [ng/HeatStick] & $0.035^{a}$ & - & 5 & $0.035^{\mathrm{a}}$ & - & 5 & $0.035^{\mathrm{a}}$ & - & 5 \\
\hline & 3-Aminobiphenyl & [ng/HeatStick] & $0.032^{a}$ & - & 5 & $0.032^{\mathrm{a}}$ & - & 5 & $0.032^{\mathrm{a}}$ & - & 5 \\
\hline & 4-Aminobiphenyl & [ng/HeatStick] & $0.051^{\mathrm{a}}$ & - & 5 & $0.051^{\mathrm{a}}$ & - & 5 & $0.051^{\mathrm{a}}$ & - & 5 \\
\hline & o-Toluidine & [ng/HeatStick] & 0.49 & 0.03 & 5 & 0.9 & 0.03 & 5 & 2.03 & 0.37 & 5 \\
\hline \multirow[t]{8}{*}{ Carbonyls } & Acetaldehyde & [ug/HeatStick] & 145 & 9 & 5 & 148 & 11 & 5 & 185 & 16 & 5 \\
\hline & Acetone & [ug/HeatStick] & 22 & 1.3 & 5 & 23.1 & 1.4 & 5 & 38.8 & 4.4 & 5 \\
\hline & Acrolein & [ug/HeatStick] & 5.2 & 0.3 & 5 & 5.1 & 0.3 & 5 & 12.9 & 1.7 & 5 \\
\hline & Butyraldehyde & [ug/HeatStick] & 17.6 & 1.4 & 5 & 20.5 & 0.7 & 5 & 24.2 & 2.9 & 5 \\
\hline & Crotonaldehyde & [ug/HeatStick] & 2.03 & 0.16 & 5 & 2.51 & 0.15 & 5 & 4.9 & 0.49 & 5 \\
\hline & Formaldehyde & {$[\mu \mathrm{g} /$ HeatStick] } & 2.07 & 0.43 & 5 & 3.12 & 0.27 & 5 & 7.73 & 0.82 & 5 \\
\hline & MEK & [ug/HeatStick] & 3.78 & 0.39 & 5 & 4.25 & 0.28 & 5 & 6.64 & 0.79 & 5 \\
\hline & Propionaldehyde & [ug/HeatStick] & 8.5 & 0.9 & 5 & 8.9 & 0.3 & 5 & 12.3 & 1.5 & 5 \\
\hline Ethylene oxide & Ethylene oxide & [jg/HeatStick] & 0.157 & 0.008 & 5 & 0.192 & 0.012 & 5 & 0.323 & 0.013 & 5 \\
\hline \multirow[t]{4}{*}{ Inorganics } & Ammonia & [ug/HeatStick] & 7 & 0.2 & 5 & 14.3 & 0.9 & 5 & 31 & 1.2 & 5 \\
\hline & NO & [ug/HeatStick] & 12.4 & 1.1 & 5 & 13.3 & 1.1 & 5 & NA & NA & 0 \\
\hline & $\mathrm{NO}_{\mathrm{x}}$ & [jg/HeatStick] & 12.8 & 1.2 & 5 & 13.6 & 1.4 & 5 & NA & NA & 0 \\
\hline & $\mathrm{CO}$ & [mg/HeatStick] & 0.242 & 0.018 & 5 & 0.324 & 0.049 & 5 & 0.542 & 0.126 & 5 \\
\hline \multirow[t]{4}{*}{ PAHs } & Benz[a]anthracene & [ng/HeatStick] & 1.45 & 0.08 & 5 & 1.07 & 0.1 & 5 & 1.3 & 0.08 & 5 \\
\hline & Benzo[a]pyrene & [ng/HeatStick] & $1^{a}$ & - & 5 & $1^{a}$ & - & 5 & $1^{a}$ & - & 5 \\
\hline & Dibenzo[a, $h]$ anthracene & [ng/HeatStick] & $0.1^{\mathrm{a}}$ & - & 5 & $0.1^{\mathrm{a}}$ & - & 5 & $0.1^{\mathrm{a}}$ & - & 5 \\
\hline & Pyrene & [ng/HeatStick] & 5.88 & 0.3 & 5 & 5 & 0 & 5 & 5.13 & 0.12 & 5 \\
\hline \multirow[t]{7}{*}{ Phenols } & Catechol & {$[\mu \mathrm{g} /$ HeatStick] } & 6 & 0.9 & 5 & 10.5 & 0.7 & 5 & 15.4 & 1.3 & 5 \\
\hline & Hydroquinone & [ $\mathrm{gg} /$ HeatStick] & 3.7 & 0.7 & 5 & 5.2 & 0.2 & 5 & 9.6 & 0.9 & 5 \\
\hline & $m$-Cresol & [ $\mu \mathrm{g} /$ HeatStick] & $0.01^{a}$ & - & 5 & 0.025 & 0.002 & 5 & 0.212 & 0.046 & 5 \\
\hline & o-Cresol & [ $\mathrm{gg} /$ HeatStick] & 0.024 & 0.002 & 5 & 0.097 & 0.007 & 5 & 0.438 & 0.1 & 5 \\
\hline & $p$-Cresol & [ug/HeatStick] & $0.02^{a}$ & - & 5 & 0.056 & 0.004 & 5 & 0.399 & 0.084 & 5 \\
\hline & Phenol & [ug/HeatStick] & $0.1^{a}$ & - & 5 & 1.6 & 0.1 & 5 & 10.9 & 1.5 & 5 \\
\hline & Resorcinol & [ug/HeatStick] & 0.02 & 0.006 & 5 & 0.022 & 0.007 & 5 & 0.052 & 0.008 & 5 \\
\hline \multirow[t]{4}{*}{ TSNAs } & NAB & [ng/HeatStick] & $3.15^{a}$ & - & 5 & $3.15^{a}$ & - & 5 & 4.32 & 0.97 & 10 \\
\hline & NAT & [ng/HeatStick] & 11.9 & 1.2 & 5 & 17.7 & 1 & 5 & 24.3 & 3 & 10 \\
\hline & NNK & [ng/HeatStick] & 5 & 0.3 & 5 & 6.6 & 0.3 & 5 & 9.9 & 1.2 & 10 \\
\hline & NNN & [ng/HeatStick] & 9.1 & 0.7 & 5 & 12.6 & 0.4 & 5 & 19.1 & 2.4 & 10 \\
\hline Vinyl chloride & Vinyl chloride & [ng/HeatStick] & $3.54^{a}$ & - & 5 & $3.54^{a}$ & - & 5 & $3.54^{a}$ & - & 5 \\
\hline \multirow{8}{*}{$\begin{array}{l}\text { Volatiles and } \\
\text { semi-volatiles }\end{array}$} & 1,3-Butadiene & [ug/HeatStick] & $0.238^{a}$ & - & 5 & 0.239 & 0.002 & 5 & 0.264 & 0.027 & 5 \\
\hline & Acrylonitrile & [ug/HeatStick] & $0.111^{a}$ & - & 5 & $0.111^{\mathrm{a}}$ & - & 5 & 0.228 & 0.017 & 5 \\
\hline & Benzene & [jg/HeatStick] & 0.298 & 0.031 & 5 & 0.358 & 0.034 & 5 & 0.684 & 0.055 & 5 \\
\hline & Isoprene & [ug/HeatStick] & 1.37 & 0.24 & 5 & 2.82 & 0.42 & 5 & 2.57 & 0.31 & 5 \\
\hline & Pyridine & [ug/HeatStick] & 4.28 & 0.35 & 5 & 6.12 & 0.42 & 5 & 7.75 & 0.23 & 5 \\
\hline & Quinoline & [jg/HeatStick] & $0.012^{a}$ & - & 5 & 0.013 & 0.001 & 5 & 0.051 & 0.003 & 5 \\
\hline & Styrene & [ug/HeatStick] & 0.314 & 0.033 & 5 & 0.415 & 0.039 & 5 & 0.641 & 0.036 & 5 \\
\hline & Toluene & [ug/HeatStick] & 1.1 & 0.1 & 5 & 2 & 0.3 & 5 & 2.1 & 0.3 & 5 \\
\hline
\end{tabular}

${ }^{a}$ Lower Limit of Quantification

Abbreviations: $\mathrm{CO}$ = carbon monoxide; $\mathrm{HPHC}$ = harmful and potentially harmful constituents; $\mathrm{MEK}$ = methyl ethyl ketone; NO, nitrogen oxide; $\mathrm{NO}_{\mathrm{x}}=$ nitrogen oxides; $\mathrm{NAB}=\mathrm{N}$-nitrosoanabasine; $\mathrm{NAT}=\mathrm{N}$-nitrosoanatabine; $\mathrm{NNK}=4$-(methylnitrosamino)-1-(3-pyridyl)-1-butanone; $\mathrm{NNN}=\mathrm{N}$-nitrosonornicotine; $\mathrm{SD}=$ standard deviation; $\mathrm{PAHs}=$ polyaromatic hydrocarbons; $T S N A s$ = tobacco-specific nitrosamines; SR-1, SR-5, and LR-3 are arbitrary names. 

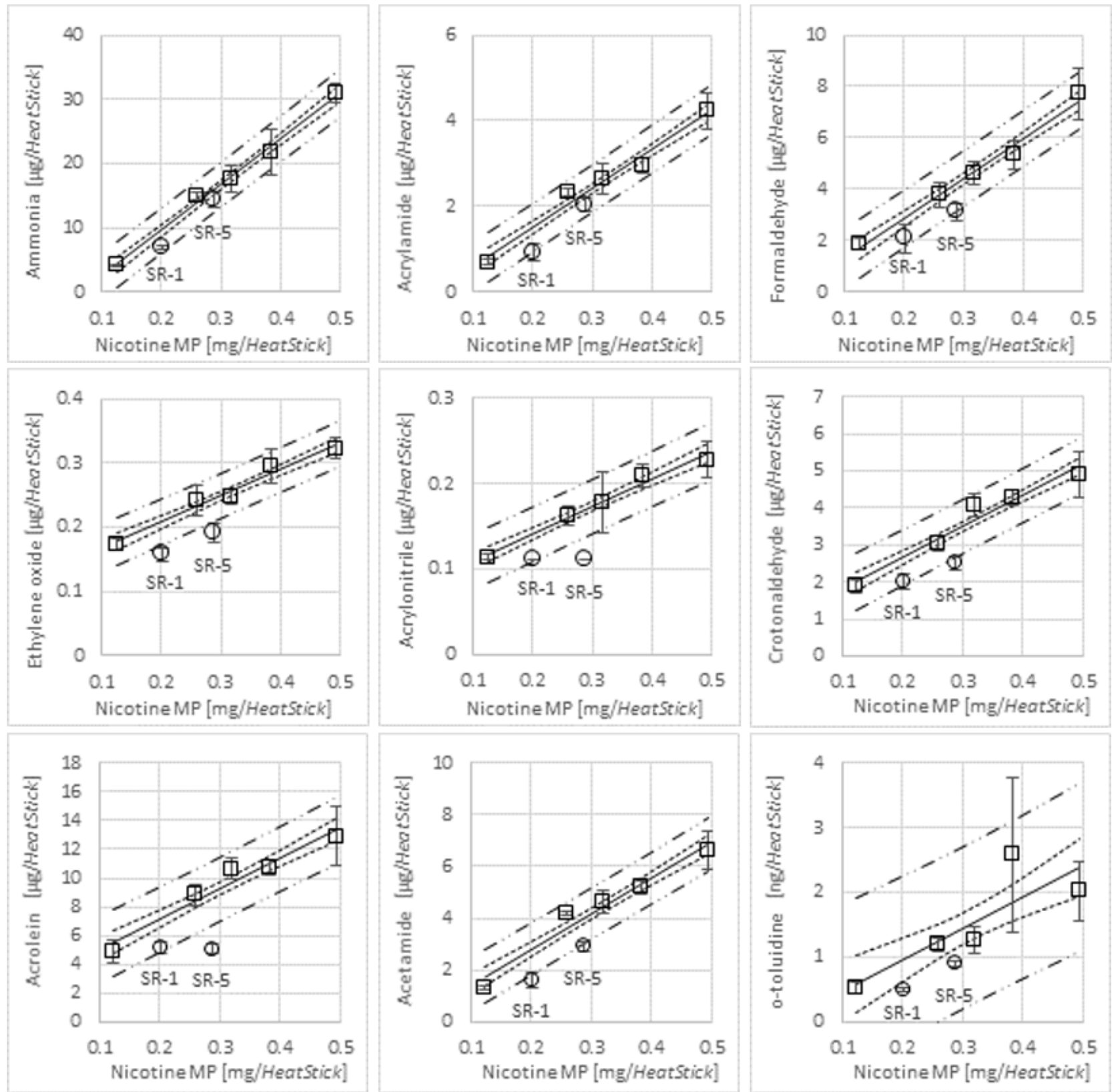

Figure 4. Graphs of HPHCs characterized by models with a linear correlation. Squares are mean values for each regimen used in the models. Circles are mean values for SR-1 and SR-5 (not included in models). Continuous line is the estimated mean. Dotted lines are the lower and upper $95 \%$ confidence limits of the estimated mean. Dashed lines are the $95 \%$ prediction intervals. Error bars are the $95 \%$ confidence limits of the mean. 

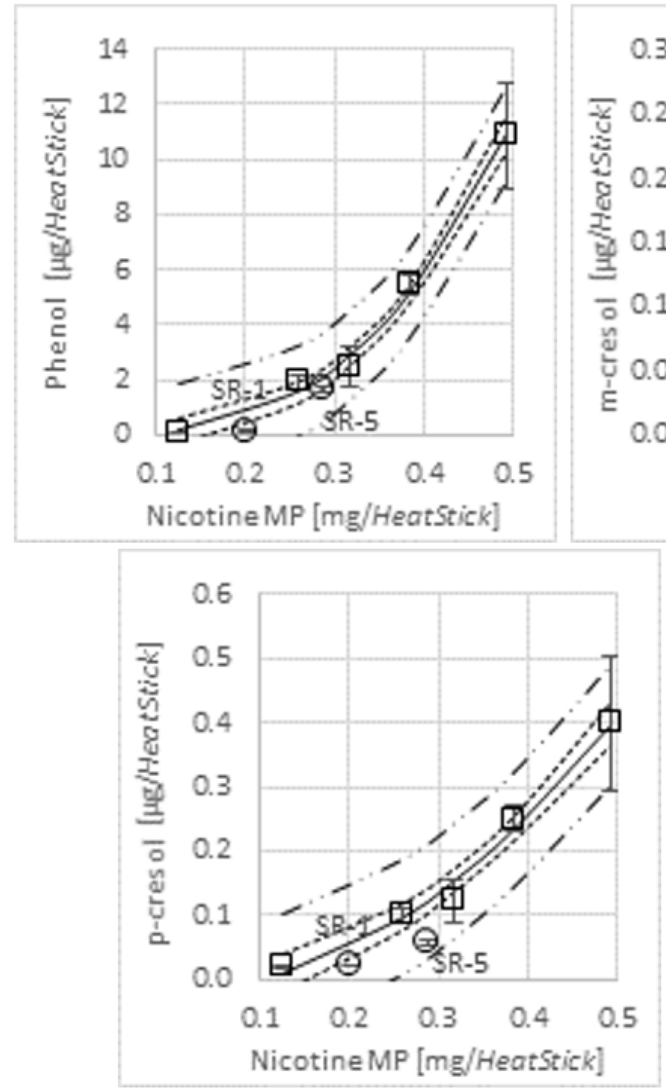
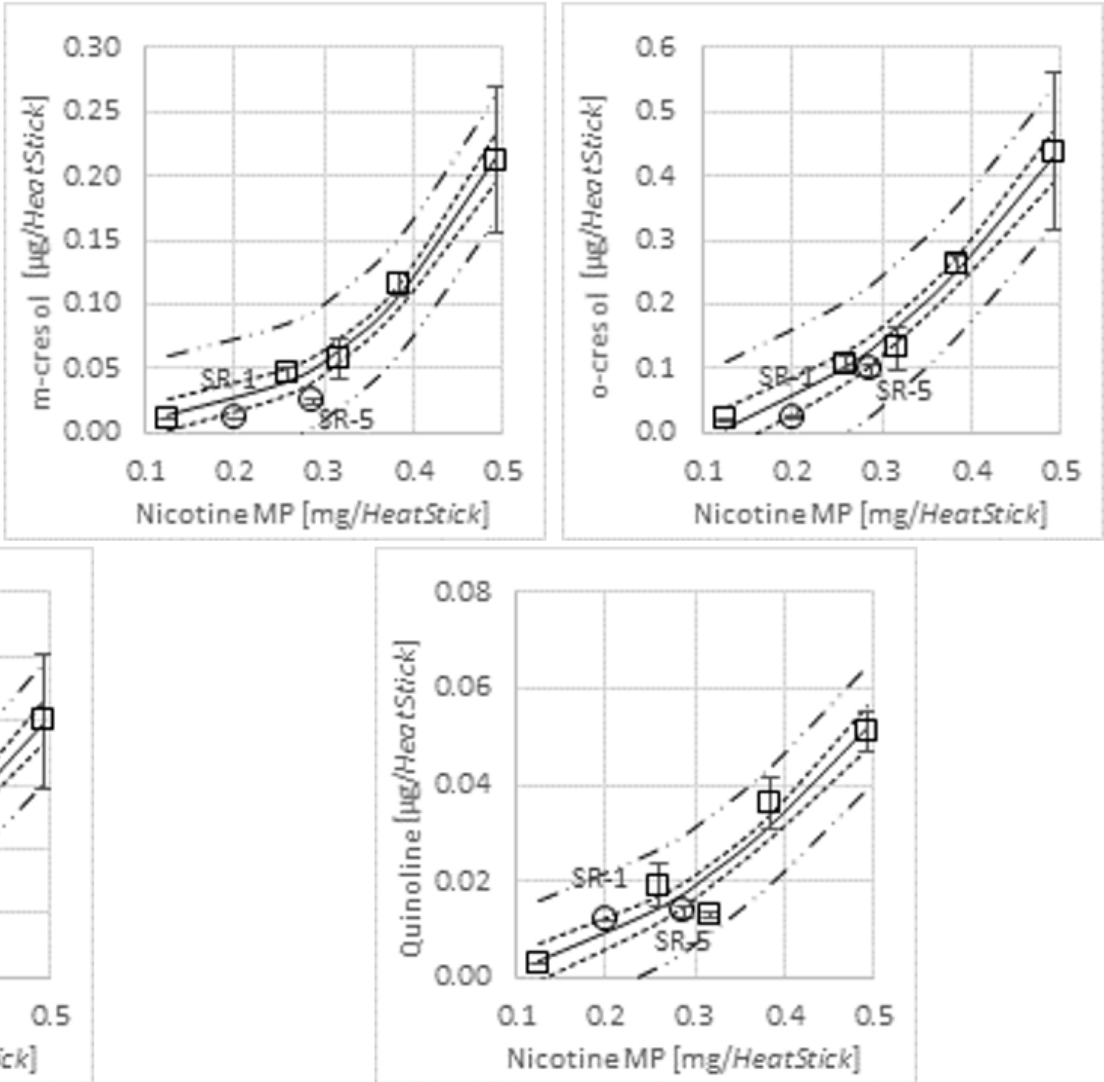

Figure 5. Graphs of HPHCs characterized by non-linear models using two regression parameters. Squares are mean values for each regimen used in the models. Circles are mean values for SR-1 and SR-5 (not included in models). Continuous line is the estimated mean. Dotted lines are the lower and upper $95 \%$ confidence limits of the estimated mean. Dashed lines are the $95 \%$ prediction intervals. Error bars are the $95 \%$ confidence limits of the mean. 

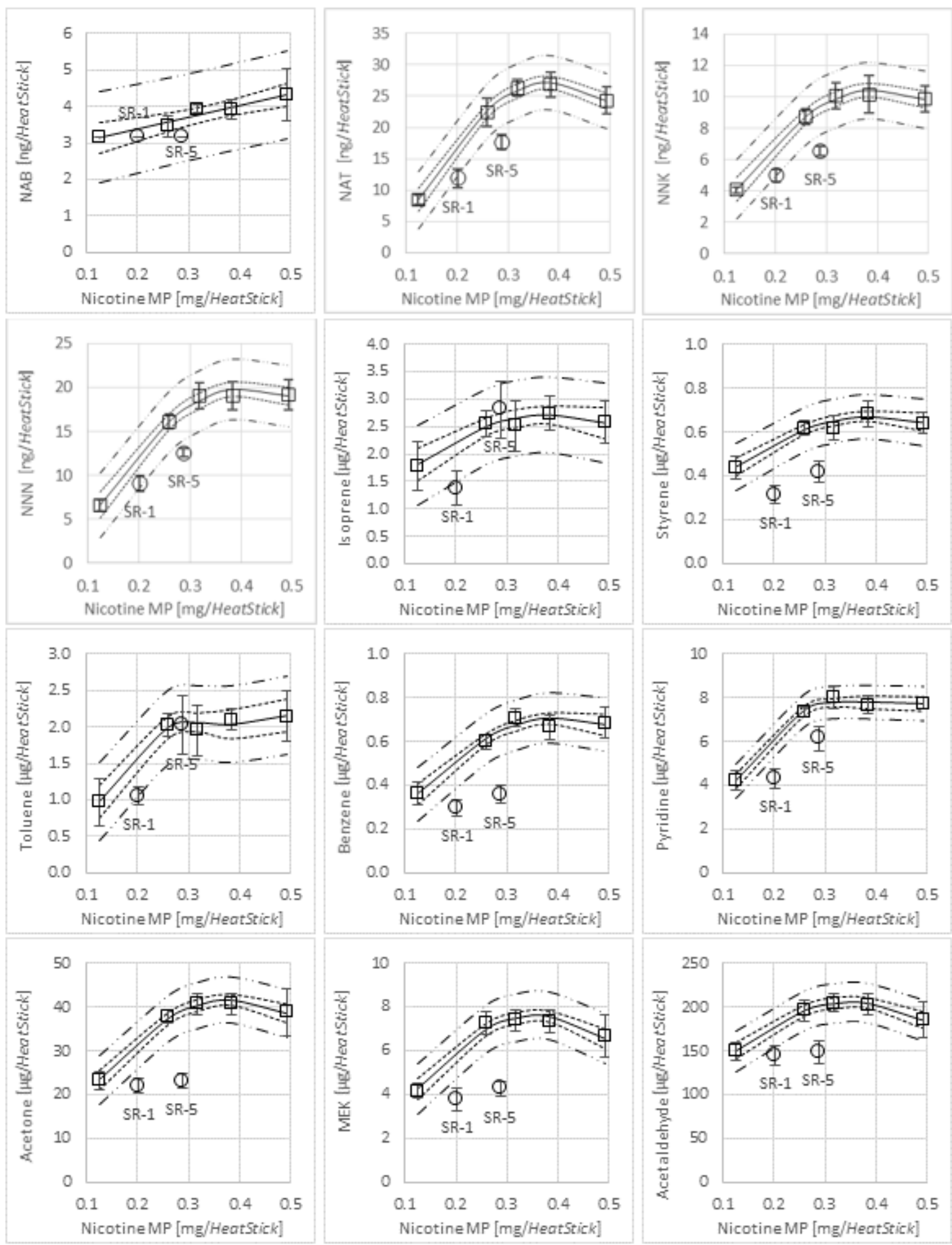

Figure 6. Graphs of HPHCs characterized by "plateau and hill". Squares are mean values for each regimen used in the models. Circles are mean values for SR-1 and SR-5 (not included in models). Continuous line is the estimated mean. Dotted lines are the lower and upper $95 \%$ confidence limits of the estimated mean. Dashed lines are the $95 \%$ prediction intervals. Error bars are the $95 \%$ confidence limits of the mean. Abbreviations: $\mathrm{CO}=$ carbon monoxide; $\mathrm{MEK}=$ methyl ethyl ketone; $\mathrm{NAB}=N$-nitrosoanabasine; $\mathrm{NAT}=N$-nitrosoanatabine; $\mathrm{NNK}=4-($ methylnitrosamino $)-1-\left(3-\right.$ pyridyl)-1-butanone; $\mathrm{NNN}=\mathrm{N}$-nitrosonornicotine; $\mathrm{NO}=$ nitrogen oxide; $\mathrm{NO}_{\mathrm{x}}=$ nitrogen oxides . 

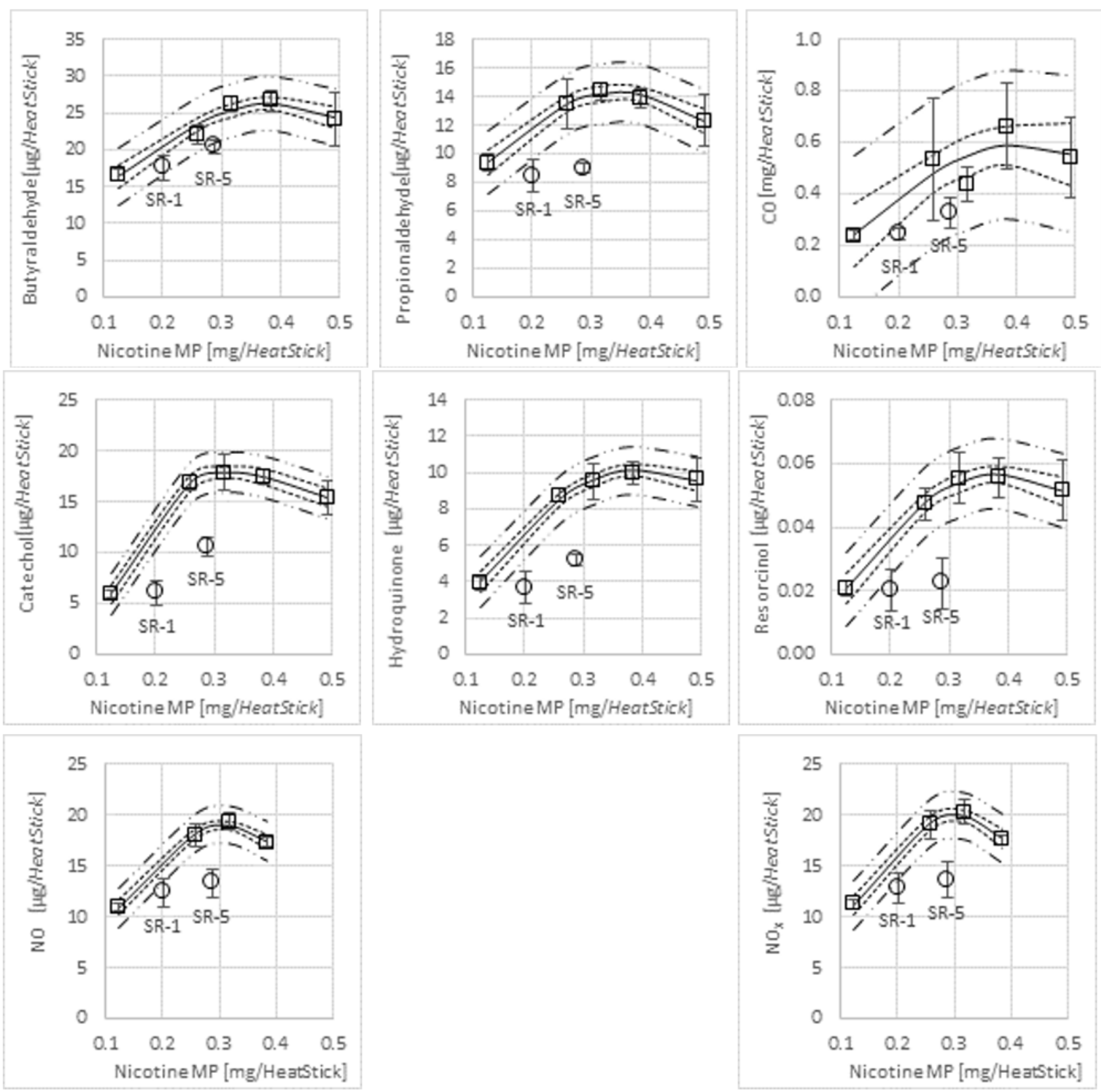

Figure 6. cont. 